\title{
A SHOSHONEAN PRAYERSTONE HYPOTHESIS: RITUAL CARTOGRAPHIES OF GREAT BASIN INCISED STONES
}

\author{
David Hurst Thomas
}

\begin{abstract}
The prayerstone hypothesis, grounded in Southern Paiute oral history, holds that selected incised stone artifacts were votive offerings deliberately emplaced where spiritual power (puha) was known to reside, accompanying prayers for personal power and expressing thanks for prayers answered. Proposing significant and long-term linkages between Great Basin incised stones and overarching Shoshonean cosmology, this article explores the prayerstone hypothesis in the context of the 3,500 incised stones documented from the Intermountain West, an assemblage spanning seven states and seven millennia. Employing object itinerary perspectives, it becomes possible to develop ritualized cartographies capable of matching oral Shoshonean traditions with specific geographic indicators. The results demonstrate that many (but not all) such incised stones are consistent with the votive emplacement of prayerstones. Multiple constellations of prayerstone practice operated across the Great Basin for more than 5,000 years and carried forward, without perceptible break, among several (but not all) Numic-speaking populations of the ethnohistoric interval. The diversity and antiquity implied by the prayerstone hypothesis suggest dramatically more complex cultural trajectories than those of Lamb's (1958) widely accepted model of a single, late, and simultaneous Numic spread across the Great Basin.
\end{abstract}

La hipótesis de las piedras votivas, basada en la tradición oral del grupo indígena Paiute del Sur, propone que ciertas piedras adornadas con motivos incisos son ofrendas votivas deliberadamente depositadas en lugares habitados por el poder espiritual (puha). Estos artefactos acompañan las peticiones de poder personal y las acciones de gracias. Este artículo propone que existen importantes relaciones de largo plazo entre las piedras votivas de la Gran Cuenca de Estados Unidos y la cosmología indígena Shoshone. Se explora la hipótesis de las piedras votivas en el contexto de las 3,500 piedras incisas documentadas en el Oeste intermontano -un conjunto que abarca siete estados y siete milenios. Empleando las perspectivas de los itinerarios de objetos es posible desarrollar cartografías ritualizadas que conectan las tradiciones orales Shoshone con indicadores geográficos específicos. Los resultados demuestran que muchas de las piedras incisas (pero no todas) fueron depositadas en contextos votivos. Múltiples constelaciones de práctica que incluyeron las piedras votivas estuvieron en uso a lo largo de la Gran Cuenca por más de 5.000 años y continuaron sin aparente interrupción entre varios grupos lingüísticos Numa (pero no todos) en el período etnohistórico. La antigüedad y diversidad representadas por la hipótesis de las piedras votivas sugieren la existencia de trayectorias culturales mucho más complejas que aquellas sugeridas en el popular modelo de Lamb (1958), quien propuso una única expansión Númica tardía a través de la Gran Cuenca.

We need to move beyond a general theory of material culture to a more detailed analysis of particular domains. We need to move from a discussion of "why things matter" to one of "why some things matter" a lot in particular places and times.

—Linda S. Cordell and Judith A. Habicht-Mauche, "Practice Theory and Social Dynamics Among Prehistoric and Colonial Communities in the American Southwest"
$\mathrm{I}$ ncised stone artifacts are known from around the globe, some approaching 100,000 years Cold (Lemke et al. 2015; Ottenhoff 2015: Table 2.1); related incising practices can perhaps be traced to premodern humans more than 450,000 years ago (Joordens et al. 2015). Such so-called portable rock art can be documented archaeologically from more than one-quarter of the states and two provinces in North America

David Hurst Thomas a Division of Anthropology, American Museum of Natural History, Central Park West at 79th Street, New York, NY 10024, USA (thomasd@amnh.org)

American Antiquity 84(1), 2019, pp. 1-25

Copyright $($ C 2018 by the Society for American Archaeology

doi:10.1017/aaq.2018.73 
(Lenik 2016:138-142; McKee and Thomas 1972; see Figure 1). The oldest come from the Gault Site (central Texas), where more than 100 incised stones span the early Paleoindian period ( 11,000-7000 cal BC) into late prehistoric times (Wernecke and Collins 2012).

Archaeologists have long puzzled over the meaning and purpose of these enigmatic stone artifacts, postulating a host of potential purposes-ranging from doodles and graffiti to ornamental art, maps, geographic indicators, depictions (of plants, animals, the natural world, clothing, textiles, fossils, basketry, and pottery), anthropomorphic representations, tattooing, meteorological and astronomical calculations, notation of time (quantity and pneumonic meaning), entopic phenomena, utilitarian functions (such as jewelry, edge grinders, cutting boards, pottery or pigment stamps, shaft straighteners, toys, and gaming pieces), heraldic devices, ethnic identifiers, flintknapping guidelines, marks of ownership, rituals and rites of passage, talismans, amulets, sympathetic magic, healing stones, accentuated or central power, and offerings (Wernecke and Collins 2012: Figure 10).

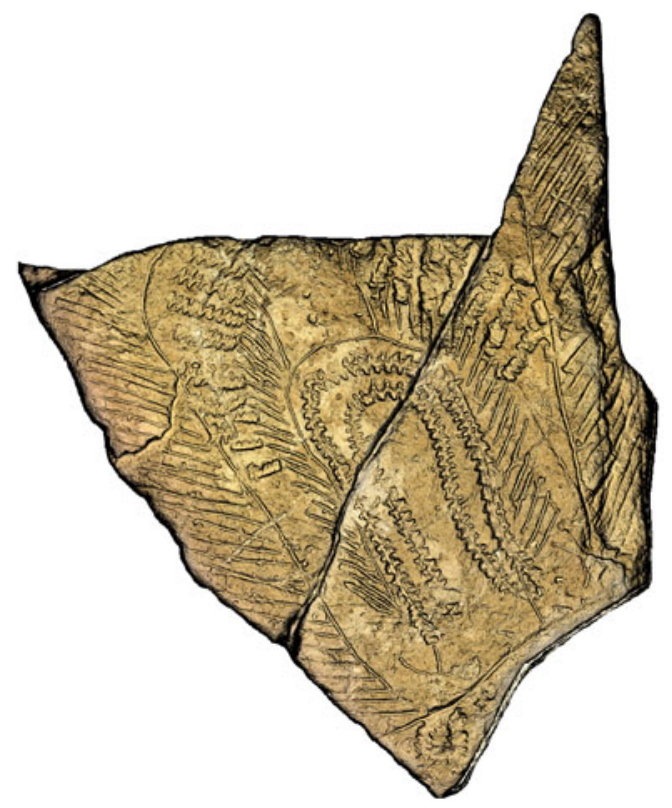

Figure 1. Incised stone from Gabbs, Nevada. Height is $17.2 \mathrm{~cm}$. (courtesy of the Nevada State Museum; photograph by Eugene Hattori).
Archaeologists have also employed multiple theoretical perspectives to study incised stone assemblages, including Marshack's (1972a, 1972b) lunar notational model, chaîne opératoire (Wadley 2012; Zilhão 2007), ethnographic analogy (d'Errico et al. 2003), stylistic zones (T. Thomas 1983a, 1983b), design grammar (Klimowicz 1988; Ottenhoff 2015), and human behavioral ecology (McGuire and Hildebrandt 2017). Here, I rely on community of practice perspectives to hypothesize that the thousands of incised stones from the Intermountain West are material representations of Shoshonean epistemologies, past and present. ${ }^{1}$ If this hypothesis proves true, then, in the terminology of Cordell and Habicht-Mauche (2012), incised stones certainly would have mattered-a lot.

\section{Defining Ancient Constellations of Ritual Practice}

\begin{abstract}
More incised stones have been found in the Great Basin region than any other parts of the world [offering] ideal conditions for the preservation and recovery of incised stones. But that alone doesn't explain their number. Clearly, incised stones were immensely popular among the foragers who inhabited this region for millennia. Few other places ... witnessed such fidelity to tradition, including the custom of decorating pebbles. $^{2}$

- Carl Schuster, Materials for the Study of Social Symbolism in Ancient and Tribal Art
\end{abstract}

Reinforcing the considerable archaeological and historic evidence demonstrating that several Numic-speaking groups employed incised stone artifacts (Figure 2; see also Supplemental Tables 1 and 2), contemporary Numic speakers believe that the hundreds of incised sandstone artifacts recovered from their sacred lands are ritualized objects, or "prayerstones": "To me...they may have a spiritual purpose.... They're giving thanks for all the medicines or plants that the mountain provides for their security. I think that would kind of explain why most of it is found in that certain area" (tribal elders quoted in O'Meara 2014:11). Integrating contemporary oral history within broader Shoshonean cosmology, the "prayerstone hypothesis" suggests that many incised Great Basin stone artifacts were 


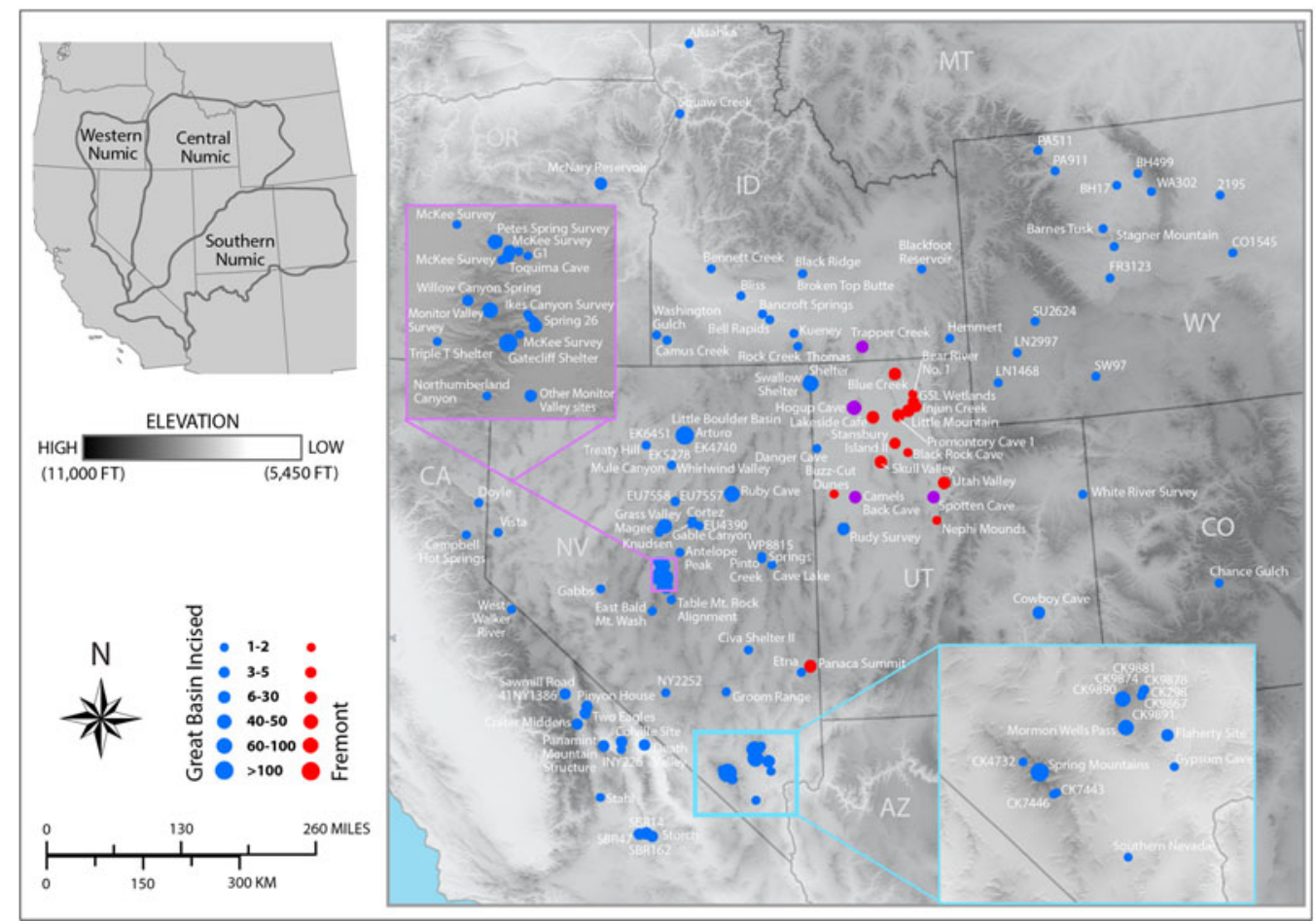

Figure 2. Distribution of $\sim 3,500$ incised stones from the Intermountain West (site identifications listed in Supplemental Table 1).

deliberately emplaced in areas of known spiritual power, accompanying prayers for personal power to become healers, for success in hunting and gambling, and to give thanks for safe passage (Fowler 2002:173-176, Figure 110; Park 1938). I explore this hypothesis-grounded in the concept of puha (power) as the hallmark of Shoshonean religious practice-within the context of 3,500 incised stones from archaeological sites across the Intermountain West (Supplementary Table 1).

Prayerstones are perceived as votive offerings - gifts given to supernatural powers connoting a connection between an object and some vow or prayer. Such offerings attempt to cement an asymmetrical relationship in which what is received is fundamentally incommensurate with what is given:

Success, health, the flourishing of crops, animals or family, these are not things that can be equated in any way with a figurine, a piece of jewellery or a sacrificial chicken.
The giving of gifts to the gods ... establishes a pattern where exchange relations may be long term, and where it may be impossible to measure the return against the investment. And it establishes that as the pattern of exchange with beings who are more powerful [Osborne 2004: 3].

Archaeological evidence of such votive practices has been recognized around the world, with considerable time depth.

The multiscalar concept of "object itineraries" entwines ritualized things with people and places by tracking the movement of individual prayerstones through time and space (Walker and Lucero 2000). ${ }^{3}$ At the artifact level, prayerstones were crafted and manipulated within multiple communities of practice, conventionally considered to be a "network of relations among people and objects mediated by actions they conduct, taking place in relation to other communities of practice and continuing over time" (Joyce 2012:150). Such communities shared ways of doing things as 
Table 1. Incised Stone Characteristics in the Intermountain West (see Supplemental Table 1 for detailed proveniences and Supplemental Table 2 for age estimates).

\begin{tabular}{|c|c|c|c|c|c|c|}
\hline Provenience & $N$ & Chronology & Selection & Enhancement & Emplacement & Reference(s) \\
\hline $\begin{array}{l}\text { Intermountain } \\
\text { Periphery }\end{array}$ & $\sim 100$ & Largely unknown & & Mannequin motifs absent & $\begin{array}{l}\text { Virtually all isolated finds; cave and } \\
\text { rockshelter placement rare }\end{array}$ & $\begin{array}{l}\text { Various (see } \\
\quad \text { Supplemental Table 1) }\end{array}$ \\
\hline $\begin{array}{l}\text { Graptolite } \\
\text { Summit } \\
\text { Constellation }\end{array}$ & $>600$ & $\begin{array}{l}\sim 3700 \text { cal BC } \\
\text { through AD } 1880 \\
\text { (Western } \\
\text { Shoshone) }\end{array}$ & $\begin{array}{l}\text { Exclusively local, fossil-rich } \\
\text { Roberts Mountain limestone }\end{array}$ & $\begin{array}{l}\text { General "poverty" of design, except } \\
\text { for walked-rocker fossil imitations, } \\
\text { most created by extremely simple } \\
\text { motions, simple rectilinear bands } \\
(39.7 \%) \text { and crosshatch designs } \\
(11.1 \%) \text {, virtually no attempt to } \\
\text { connect motifs on front and back } \\
\text { sides, edges almost always kept in } \\
\text { their original form, unshaped in } \\
\text { any way (except during the late } \\
\text { nineteenth century), many marked } \\
\text { during multiple episodes with } \\
\text { different tools, virtually all } \\
\text { deliberately overmarked (92\%) } \\
\text { with unlike motifs, despite plenty } \\
\text { of blank space left on the same } \\
\text { surface; markings, curvilinear } \\
\text { elements, and mannequin } \\
\text { compositions rare (both only } 2 \% \text { ), } \\
\text { oil staining and surface polish } \\
\text { common }\end{array}$ & $\begin{array}{l}\text { Logistic bighorn hunting camps } \\
\text { (pre-1000 cal BC); residential } \\
\text { bases (post cal AD 1); Gatecliff } \\
\text { Shelter favored and Toquima } \\
\text { Cave deliberately avoided; many } \\
\text { deliberately emplaced near } \\
\text { springs and massive exposures of } \\
\text { Roberts Mountain limestone } \\
\text { formation, trailside shrines, fall/ } \\
\text { winter piñon camps; 1880s } \\
\text { Shoshonean house floor, highly } \\
\text { concentrated emplacement with } \\
\text { isolated finds rare }\end{array}$ & $\begin{array}{l}\text { Kennett et al. 2014; } \\
\text { D. Thomas 1983, } \\
\text { 1988; T. Thomas } \\
\text { 1983a, 1983b; } \\
\text { Schuster and Carpenter } \\
1988\end{array}$ \\
\hline $\begin{array}{l}\text { Ruby Cave } \\
\text { Constellation }\end{array}$ & 53 & $\begin{array}{l}2500 \text { cal BC } \\
\text { through last few } \\
\text { centuries } \\
\text { (Western } \\
\text { Shoshone?) }\end{array}$ & $\begin{array}{l}\text { Nearly half made of slate, } \\
\text { limited use of Roberts } \\
\text { Mountain limestone (despite } \\
\text { nearby access) }\end{array}$ & $\begin{array}{l}33 \% \text { mimic mannequin model } \\
\text { protocols, including the stylized } \\
\text { fringed flap, the zigzag check } \\
\text { design, and the feather-like } \\
\text { motif-each apparently without } \\
\text { deliberate composition or } \\
\text { positioning }\end{array}$ & $\begin{array}{l}\text { Logistic bighorn hunting camps } \\
\text { (pre- } 1000 \text { cal BC); unsatisfactory } \\
\text { for residential base, likely } \\
\text { became a personal power place }\end{array}$ & Ottenhoff 2015 \\
\hline
\end{tabular}


Table 1. Continued.

\begin{tabular}{|c|c|c|c|c|c|c|}
\hline Provenience & $N$ & Chronology & Selection & Enhancement & Emplacement & Reference(s) \\
\hline $\begin{array}{l}\text { Little Boulder } \\
\text { Basin } \\
\text { Constellation }\end{array}$ & 172 & $\begin{array}{l}\text { cal AD } 1 \text { through } \\
\text { historic period } \\
\text { (Western } \\
\text { Shoshone) }\end{array}$ & $\begin{array}{l}\text { Platy sedimentary rocks from } \\
\text { local alluvium; massive } \\
\text { outcrop of fossil-rich } \\
\text { Roberts Mountain limestone } \\
\text { ignored }\end{array}$ & $\begin{array}{l}\text { More than one-quarter consistent } \\
\text { with the mannequin model, } \\
\text { including vertically rising zigzags } \\
\text { separated by blank bands } \\
\text { (presumably torso decorations) } \\
\text { and fringe flap depictions; } \\
\text { generally depict motifs as isolates, } \\
\text { with no suggestion of anatomical } \\
\text { format; walked-rocker technique } \\
\text { virtually absent (1.2\%); higher } \\
\text { frequency of surface preparation } \\
\text { (9.2\%); frequent overmarking of } \\
\text { individual motifs, surface polish } \\
\text { rare }(2.5 \%)\end{array}$ & $\begin{array}{l}\text { Long-term, short-term, and } \\
\text { "generalized" residential bases by } \\
\text { extended families (no houses } \\
\text { evident); isolated finds rare }\end{array}$ & $\begin{array}{l}\text { Cannon 2010; Fenner } \\
2013\end{array}$ \\
\hline $\begin{array}{l}\text { Inyo-Mono } \\
\text { Cluster }\end{array}$ & $\sim 100$ & $\begin{array}{l}\text { Largely undated, but } \\
\text { continuing into } \\
\text { the nineteenth } \\
\text { century (Panamint } \\
\text { Shoshone) }\end{array}$ & $\begin{array}{l}\text { Mostly slate with some use of } \\
\text { locally abundant Roberts } \\
\text { Mountain limestone in the } \\
\text { northern Inyo Mountains }\end{array}$ & $\begin{array}{l}\text { Familiar assortment of design } \\
\text { elements (mostly bands, transverse } \\
\text { bisecting lines, chevrons, } \\
\text { crosshatching, and random straight } \\
\text { lines) evident at Graptolite } \\
\text { Summit; a few follow the } \\
\text { mannequin model, with a } \\
\text { horizontal divider, two vertical } \\
\text { pair straps, "grass skirt" with } \\
\text { "feathers" and "fringed flap"; } \\
\text { walked-rocker technique rare and } \\
\text { not employed for fossil imitations }\end{array}$ & $\begin{array}{l}\text { Short-term hunting camps (early) } \\
\text { and fall/winter piñon camps } \\
\text { (later); large proportion finished } \\
\text { into pendants; mostly isolated } \\
\text { finds }\end{array}$ & $\begin{array}{l}\text { Bettinger 1989; Schuster } \\
\text { and Carpenter 1988; } \\
\text { Enfield-Walker } \\
\text { collection } \\
\text { (unpublished) }\end{array}$ \\
\hline
\end{tabular}


Table 1. Continued.

\begin{tabular}{|c|c|c|c|c|c|c|}
\hline Provenience & $N$ & Chronology & Selection & Enhancement & Emplacement & Reference(s) \\
\hline $\begin{array}{l}\text { Las Vegas } \\
\quad \text { Constellation(s) }\end{array}$ & $\sim 1,100$ & $\begin{array}{l}\text { Older than } 1500 \text { cal } \\
\text { BC lasting } \\
\text { through } \\
\text { eighteenth/ } \\
\text { nineteenth } \\
\text { centuries } \\
\text { (Southern Paiute) }\end{array}$ & $\begin{array}{l}\text { Almost exclusively local } \\
\text { sandstone }\end{array}$ & $\begin{array}{l}\text { Mannequin compositions and } \\
\text { derivative motifs dominant; } \\
\text { curvilinear elements common } \\
(32.1 \%) \text {; simple rectilinear bands } \\
(39.7 \%) \text { and crosshatch designs } \\
(11.1 \%)\end{array}$ & $\begin{array}{l}\text { Almost half clustered in Spring and } \\
\text { Sheep mountains, caves, and } \\
\text { rockshelters, isolated finds very } \\
\text { rare }\end{array}$ & $\begin{array}{l}\text { Dixon 1987; Klimowicz } \\
\text { 1988; Santini 1974; } \\
\text { Schuster and Carpenter } \\
1988\end{array}$ \\
\hline $\begin{array}{l}\text { Archaic } \\
\text { Bonneville } \\
\text { Basin Cluster }\end{array}$ & $\sim 100$ & $\begin{array}{l}\sim 5000 \text { cal BC until } \\
\text { Fremont }\end{array}$ & $\begin{array}{l}\text { Variety of local sources; } \\
\text { pebbles and cobbles avoided }\end{array}$ & $\begin{array}{l}\text { Strong carryover into Great Basin } \\
\text { Archaic rock art }\end{array}$ & $\begin{array}{l}\text { Almost entirely Great Basin caves } \\
\text { and rockshelters; absent from } \\
\text { Colorado Plateau }\end{array}$ & $\begin{array}{l}\text { Various (see } \\
\quad \text { Supplemental Table 1) }\end{array}$ \\
\hline $\begin{array}{l}\text { Fremont and } \\
\text { Promontory } \\
\text { Constellation }\end{array}$ & $>200$ & $\begin{array}{l}650 \mathrm{cal} \mathrm{BC}-\mathrm{cal} \text { AD } \\
1300\end{array}$ & $\begin{array}{l}\text { Surprisingly broad range of } \\
\text { raw materials: quartzite, } \\
\text { volcanic tuff, slate, shaley } \\
\text { sandstone, limestone, } \\
\text { calcite, and shale; stream } \\
\text { pebbles and cobbles also } \\
\text { frequently incised }\end{array}$ & $\begin{array}{l}\text { Mannequin compositions dominant } \\
\text { (with distinct eyes, tear streaks, } \\
\text { decorated torsos, fringe, and } \\
\text { necklaces); strong carryover into } \\
\text { Fremont rock art; parallel } \\
\text { anthropomorphic motifs } \\
\text { unmistakable in Fremont clay } \\
\text { figurines, with men wearing kilts, } \\
\text { women wearing aprons or skirts, } \\
\text { elaborate pendants, belts, and } \\
\text { necklaces, perhaps suggestive of } \\
\text { ceremonial dolls (e.g., Aikens } \\
\text { 1970:192; Green 1964; Schuster } \\
\text { and Carpenter 1988:936-937) }\end{array}$ & $\begin{array}{l}\text { Continued used of Great Basin } \\
\text { caves; farming and foraging } \\
\text { residential bases; absent from the } \\
\text { Colorado Plateau }\end{array}$ & $\begin{array}{l}\text { Various (see } \\
\quad \text { Supplemental Table 1) }\end{array}$ \\
\hline
\end{tabular}


Table 2. Provenience and Age of Incised Stones Recovered from Gatecliff Shelter.

\begin{tabular}{lll}
\hline & & \\
Horizon & Age & $\begin{array}{l}\text { No. of } \\
\text { Incised Stones }\end{array}$ \\
\hline $\begin{array}{l}\text { Horizon 1 } \\
\text { Horizon 1/2 }\end{array}$ & cal AD 1240-1400 & 16 \\
Horizon 2 & & 27 \\
Horizon 2/3 & cal AD 925-1105 & \\
Horizon 3 & & 60 \\
Horizon 4 & & 77 \\
Horizon 4/5 & cal AD 265-495 & \\
Horizon 5 & & 68 \\
Horizon 6 (Late) & 195 cal BC-cal AD 50 \\
Horizon 6 & & 151 \\
Horizon 6 (Early) & $1550-1365$ cal BC & - \\
Horizon 7 & $1625-1535 \mathrm{cal} \mathrm{BC}$ & 2 \\
Horizon 8 & $1640-1615 \mathrm{cal} \mathrm{BC}$ & 4 \\
Horizon 9 & $1910-1710 \mathrm{cal} \mathrm{BC}$ & 2 \\
Horizon 10 & $2530-2395 \mathrm{cal} \mathrm{BC}$ & 1 \\
Horizon 11 & $2875-2775 \mathrm{cal} \mathrm{BC}$ & 2 \\
Horizon 12 & $3310-3155 \mathrm{cal} \mathrm{BC}$ & - \\
Horizon 13 & $3560-3485 \mathrm{cal} \mathrm{BC}$ & - \\
Horizon 14 & $3690-3600 \mathrm{cal} \mathrm{BC}$ & 1 \\
Horizon 15 & $3920-3845 \mathrm{cal} \mathrm{BC}$ & - \\
Horizon 16 & $4220-4110 \mathrm{cal} \mathrm{BC}$ & - \\
No provenience & & 17 \\
Total & & 428 \\
\hline $\begin{array}{l}\text { Hote: After Th } \\
\text { Hon }\end{array}$ & \\
\hline
\end{tabular}

Note: After T. Thomas (1983a, Table 5) and Kennett et al. (2014).

learned and reproduced during everyday life. Due to the repetition of practices learned in certain ways and passed along, communities of practice can persist over considerable spans of time-but they are difficult to isolate archaeologically (Cordell and Habicht-Mauche 2012:3-4).

"Constellations of practice" emerge at a broader scale "through the articulation of separate communities of practice that share common historical roots, or have members in common, or share certain things, or engage in overlapping styles or related discourses" (Joyce 2012:150). Because constellations have less face-to-face intentionality than communities, their material consequences can help define identities at a regional scale-even if it remains difficult to pin down the specific populations involved.

By viewing incised stones as material things embedded within broader genealogies of practice (Hahn and Weiss 2013; Joyce 2000; Kopytoff 1986; Miller 1998; Pauketat 2013:32), the prayerstone hypothesis attempts to complement and expand the prevailing "gastric" paradigm that has long dominated Great Basin anthropology (Kelly 1999; Morgan et al. 2014; Steward 1938:46; Zeanah and Simms 1999:118).

\section{The Power of Puha in Shoshonean Cosmology}

Cosmology changed contours from one [Shoshonean] group to another and even within the same group.

—Sven Liljeblad, "The Religious Attitude of the Shoshonean Indians"

Considerable archaeological evidence links several ethnohistoric Shoshonean communities to the manufacture and use of incised stone artifacts-including those found inside historic period houses in the Panamint Range and Grass Valley, plus others emplaced at Colville Rock Shelter, Two Penny Ridge, Coyote Springs Rockshelter, Gatecliff Shelter, and Trapper Cliff Shelter (Supplemental Table 2). Classic Great Basin ethnographies contain a wealth of clues about the workings of Shoshonean religion and epistemology. Although Shoshonean people spoke closely related languages, participated in the same basic culture, and shared a common epistemology, an acceptable degree of variability characterized each. The prayerstone hypothesis attempts to link a key element of Shoshonean material culture to its cosmological genesis.

Shoshonean cosmology is driven by the foundational concept of puha. Loosely translated as "power," puha is a living, kinetic force that moves through the existing universe without boundaries or dividing lines separating animals, plants, and rocks-all considered to be "people" talking one language (Vander 1997:217; see also Arnold and Stoffle 2006; Fowler 2002; Liljeblad 1986:643-644; Miller 1983:69, 78; Steward 1933:224-226; Stoffle and Zedeño 2001; Van Vlack 2018). Shoshonean epistemology maintains that puha is nonrandomly concentrated in certain people, places, and objects. Power places-particularly those that work well-can survive across generations, with repeated use and veneration increasing the power of place exponentially (Fowler 2002:170; Morgan et al. 2014; Park 1938). Ritual knowledge is kept alive by powerful places, where effective rituals 
"anchor" the collective memory and help ensure success in the future (Basso 1996). Power-place mystique operates cross-culturally in settings almost universally recognized for their intrinsic power-the most obvious being mountains, caves, oceans, volcanoes, springs, box canyons, and dramatic geological outcrops. More mundane places can also become puha-laden, ritualized settings because of their unique life histories-including mortuary spots, lightning strikes, key battles won or lost, and places of extraordinary healing (Stoffle and Zedeño 2001).

Shoshoneans have long been attracted to places where power resides. Caves and mountains were sometimes visited by those wishing to become doctors. Hot springs and certain rock outcrops were visited to cure illness or to protect one's self or family. Myth-specific practices among the Northern Paiute were "mapped onto the landscape in a myriad of place names, often associated with individual features of the geography such as rock formations, specific caves or springs, petroglyph panels, trails, washes or arroyos, and much more. People could not move about the landscape without thinking of or feeling these links to the past" to the extent that the paths to sacred places also became sacred (Fowler 2002:170; see also Lowie 1924:228229; Miller 1983:81; Powell in Fowler and Fowler 1971:39; Steward 1933:308; Van Vlack 2018).

Significant power places were typically memorialized by votive offerings, stone cairns and features, rock art, and geoglyphs directly linking people to natural phenomena, often in the attempt to enlist such puha to help people, or a shaman seeking a spirit helper. Morgan and colleagues (2014) make a strong case that Campo Borrego, an alpine site in the White Mountains, was a ceremonial site where individuals seeking puha constructed more than 200 cairns, pits, and other stacked-rock constructions. Zedeño's (2009) concept of "index objects" helps translate this Shoshonean ritualized cartography to the artifact level, such as inherently animate objects (i.e., red paint, crystals, and fossils), objects relating to the soul of living beings (such as effigies and animal parts), and objects enhancing communication (including smoking pipes, roots of hallucinogenic plants, and leaves of smudging or incense plants). Because of their widespread regional distribution and long temporality, prayerstones may be considered a kind of index object that marks particular sites and places that have been ritualized through practice and object deposition. This "ritual cartography" of Great Basin landscapes links oral Shoshonean tradition to specific geographic indicators "connecting in predictable ways with other types of places to form landscapes illustrating a culturally-based logic of place and landscape" (Stoffle et al. 2004:24; Supplemental Table 3). And those "predictable ways" are available for testing in the empirical world.

\section{The Prayerstone Hypothesis}

Objective archaeological explanation can gain a great deal, without any loss of analytical rigor, by treating oral traditions not as scientific unassimilable myths but as a primary source of evidence and interpretation of past social formulations.

-Peter Whiteley, "Archaeology and Oral Tradition: The Scientific Importance of Dialogue"

The prayerstone hypothesis holds that selected incised stone artifacts functioned as ritualized index objects among some Shoshonean communities (Brown and Walker 2008:298). James Santini first articulated this view by suggesting that incised stones of southern Nevada "represent an expression of gratitude or request for future help incident to the makers' food gathering practices. These concepts may be interwoven with aspects of prehistoric mythology such as Southern Paiute myths" (1974:12; emphasis in original). Santini's suggestion was reinforced during consultations among seven Southern Paiute groups and the University of Arizona's Bureau of Applied Research in Anthropology in a program specifically exploring the articulation of traditional religious and cultural values to significant archaeological sites, objects, places, and landscapes among contemporary Southern Paiute people (Arnold and Stoffle 2006; Stoffle et al. 2000, 2004, 2005, 2008).

Southern Paiute elders emphasized as an example the spiritual and symbolic importance of the Spring Mountains:

[We] believe that the Great Spirit is still sitting there in the mountain, and he's listening to you. And he's not going to come out and 
grab you, or whatever. He's going to wait until you decide to talk to him.... It was a special mountain, and they respected that, they didn't go up there, unless they gave prayer, and went up into the mountain and did their thing and came right back [quoted in O'Meara 2014:11]

Archaeological evidence from the Spring Mountains demonstrates long-term occupation, and hundreds of incised stones have been collected here, some from caves and rockshelters (Klimowicz 1988:58; Santini 1974; Tuohy 1986:230, Table 3). Southern Paiute elders are familiar with such incised artifacts because these votive objects were still used within contemporary memory. "I would think that they're prayer stones," commented one elder, "an offering to the mountain because, to an Indian, they all have life, the trees, the rocks, and everything like that, and that mountain, it all has life" (quoted in O'Meara 2014:8). Another added that "the high concentrations of incised stones are indicative of their function as prayerstones, placed to perform an ongoing function associated with prayer and other spiritual activities" (quoted in O'Meara 2014:10).

The prayerstone hypothesis links Shoshonean oral histories to thousands of incised stones from the Intermountain West by arguing that the life trajectories and depositional histories of many (but not all) such artifacts reflect a Shoshonean practice of emplacing prayerstones as votive offerings and expressions of thanks. Specific object itineraries reflect a sequential, recursive process that transformed simple flat rocks into prayerstones: (1) the geological creation of stone blanks, (2) selection of stones for potential ritualization, (3) enhancement and empowerment through appropriate marking and performance, (4) and ritualized emplacement to draw out, memorialize, and express gratitude to the intrinsic puha residing there. This open-ended cartography also admits the possibility of additional performance rituals long after the initial transformations took place (Joyce 2012; Joyce and Gillespie 2015; see also Carroll et al. 2004:128).

The prayerstone hypothesis tracks how incised stone artifacts move through time and space, fragmenting and accumulating in their travels (Hahn and Weiss 2013; Walker 1995; Walker and Lucero 2000; Supplemental Table 1). The prayerstones that populated the Great Basin landscape reflect a deliberate relationship between material culture and puha (power) places-a central religious concept that still underwrites shared Shoshonean worldviews (Figure 3 ).

\section{A Heuristic Mannequin Model}

You don't need to know why a golf course has 18 holes to play golf.

- Lord Raglan, as quoted in Mark Siegeltuch,

"Lunar Calendars or Tribal Tattoos?"

Julian Steward (1937:122) recognized the association between incised stone artifacts and Great Basin caves-a key feature of the prayerstone hypothesis developed here (see also Aikens 1970; McKee and Thomas 1972). The stylistic zones of Trudy Thomas (1983a, 1983b) demonstrated the remarkable variability in incised stone assemblages across the Intermountain West (see also Budy 1987; Fenner 2013; Klimowicz 1988; Ottenhoff 2015; Santini 1974; Schuster 1968; Schuster and Carpenter 1988:891; Tuohy 1986). But attempting to isolate specific constellations of ritual practice requires more detailed methodologies capable of capturing the complex spatial, structural, and compositional variability in these Intermountain incised stone assemblages.

I find some heuristic merit in a "mannequin model," derived and modified by Carl Schuster (1968), whose foundational research was posthumously expanded into a massive 12-volume monograph, edited and written by Edmund Carpenter (Schuster and Carpenter 1988; see also Schuster and Carpenter 1996). Suggesting that incised stones are best compared through a series of relatively objective landmarks designed to define the underlying structure, Schuster proposed that Intermountain incised stones often represent garments and/or clothed human beings. Some prayerstone motifs unquestionably do this; others certainly do not. Either way, Schuster's protocols help define compositional strategies that transcend simple motif comparisons.

The mannequin model begins with a horizontal divider that establishes a waistline, with the upper part corresponding to the head or bust 


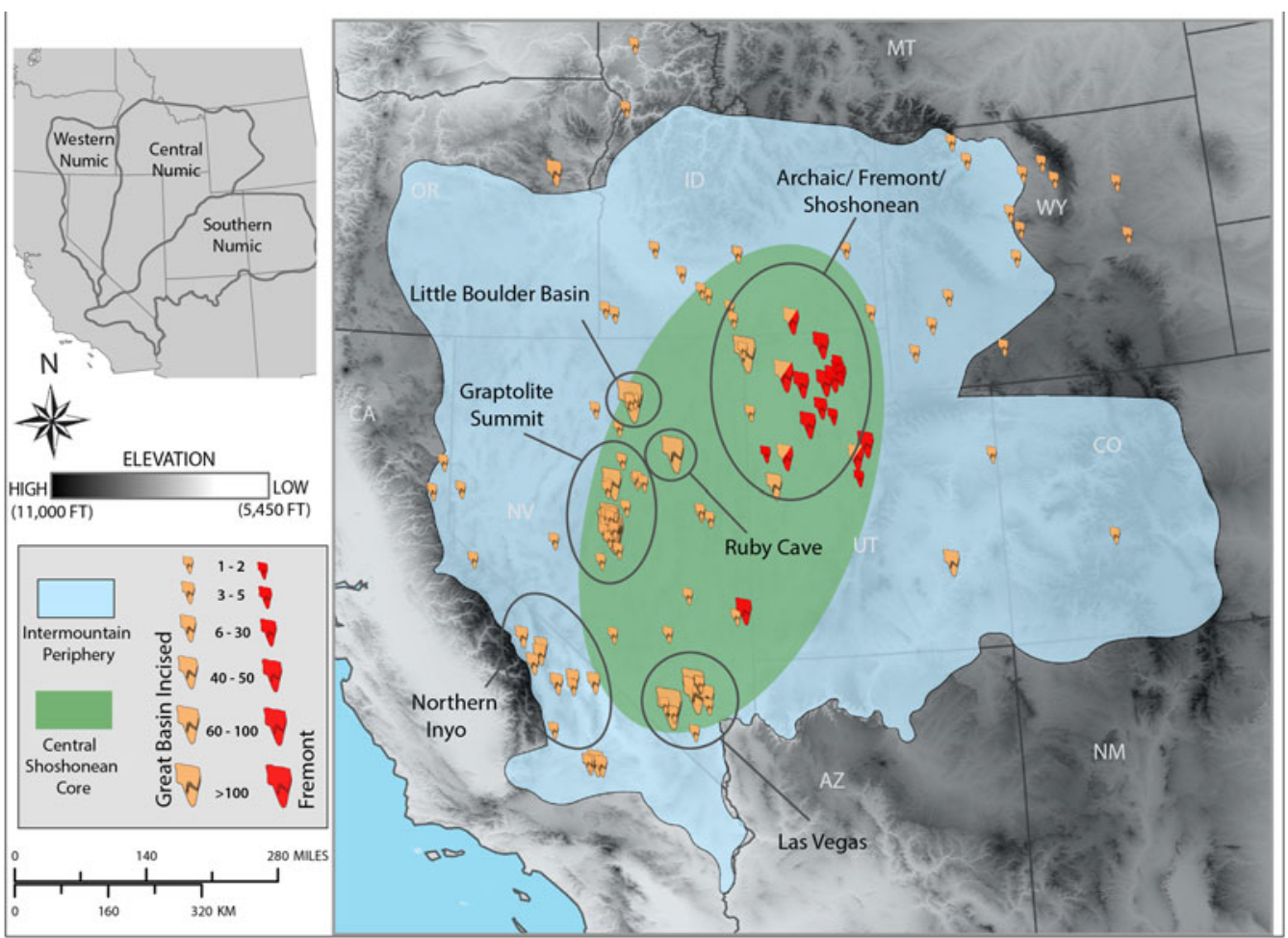

Figure 3. Constellations of ritual practice for prayerstones within the Central Shoshonean core (site identifications listed in Supplemental Table 1).

(Figure 4). To Schuster, the two strap-like vertical bands near the "shoulders" of many incised stones likely represented apron straps or maybe the seams of men's nineteenth-century shirts from the northwest plains, plateau, and Great Basin. Several stones also show what appears to be a necklace or perhaps a U-shaped neck flap with borders and fringes. Schuster saw the paired, opposed zigzag lines (here aligned vertically) as clothing seams, with the zigzags perhaps depicting painted designs on the garment itself (Schuster and Carpenter 1988:894, Figures 977-981).

Figure 5 expands this mannequin model on two incised stones from Nevada's Spring Mountains, demonstrating other ways that the opposed zigzag pattern played out in practice. On the left, an entire human figure has vertically rising, opposed zigzags, which Schuster interpreted as a stylized rendering of the chest area. To the right is a "shorthand" rendition of the same zigzag motif, this time depicted as an isolated covering of the entire working surface.
In Schuster's mannequin heuristic, the space "below the belt" sometimes had bunched fringes or a "fringed flap," as on the Death Valley artifact (Figure 4, left), often with two "straps" at the top to create "a hanging pouch" (Schuster and Carpenter 1988:846). The compelling incised stone from Gabbs (Figure 1) renders the fringed flap motif in more detail, with loops defined by a walked-rocker technique and individual incisions defining the "fringes." Figure 4 (left) depicts a more simplified fringed flap, and Figure 5 (left) does the same, adding a stylized rendering of the chest area. Schuster thought this "flap within a flap" might attempt to show the back and front simultaneously. Like the zigzag motif, fringed flaps were considered so fundamental to the mannequin model that they often appeared alone.

Although Schuster crafted this mannequin model as a genealogical iconography capable of tracing "roots in the Paleolithic and branches among the living" (Schuster and Carpenter 1988:796), he also warned against overinterpreting 


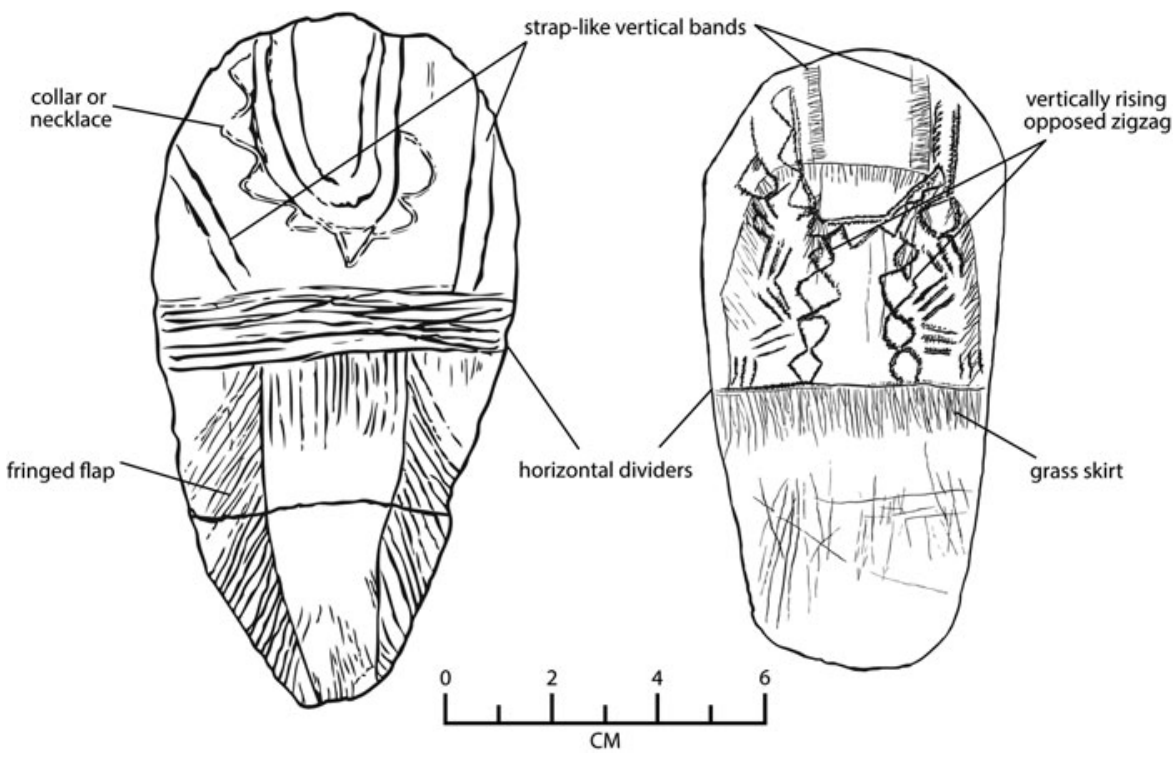

Figure 4. Two southwestern Great Basin incised stones demonstrating the basics of Schuster's mannequin model. Left: Death Valley National Monument (Alice Hunt Collection; after Hunt 1960:Figure 72f; Schuster and Carpenter 1988:895, Figure 847). Right: Panamint Valley (Inyo County; Allen Sanborn collection; after Schuster and Carpenter 1988:841, Figure 846).

these designs, cautioning that "correspondences between incised stones and modern garments may be more apparent than real. We will probably

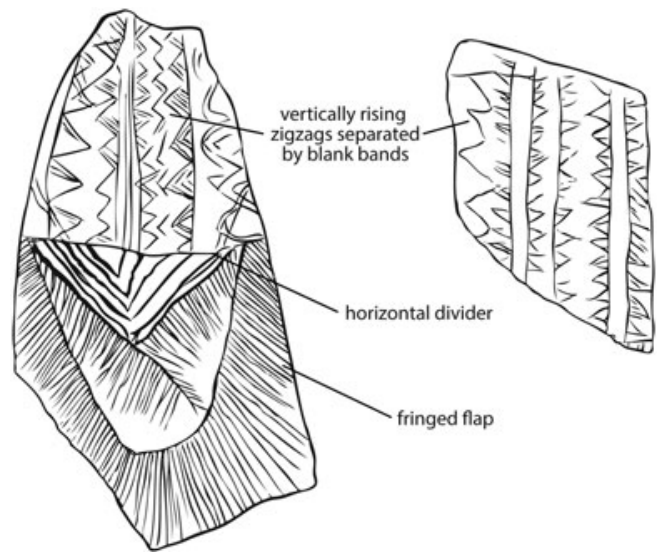

Figure 5. Two incised stones from Lovell Canyon (Spring Mountains, Nevada). Schuster identified the distinctive fringed flap motif situated immediately below the horizontal divider (right), with opposing zigzags apparent across the "chest area" (Schuster and Carpenter 1988:916, Figure 1057). Left: after Schuster and Carpenter 1988:916, Figure 1057; see also Dixon, 1987:244; right: after Schuster and Carpenter 1988:917, Figure 1059; see also Dixon, 1987: 223. Dimensions unavailable. never know what garments the engravers of these stones wore or if their engravings represented garments-worn or designs-remembered" (Schuster and Carpenter 1988:846). I agree. While agnostic about his overarching perspectives on global incised stone traditions, I do see Schuster's mannequin mapping as a simple, relatively operational, first-order heuristic for teasing out underlying structure and style in Great Basin rock marking strategies-nothing more.

It matters not (to me) whether the "fringed flap" motif represents ancient Siberian garb, Inuit overcoats, or Algonquin deerskin shirtsmaybe they aren't fringed flaps at all. What's important (to me) is that significantly different permutations of incised stone motifs and designs were systematically repeated across the Intermountain West (at a local level), sometimes lacking any reference to anatomical placement at all. Whatever the meaning to the inscribers, the cosmological symbolism encoded in incised stones provides a material entry point for defining constellations of ritual practice that may have operated within the Great Basin. These votive practices spanned at least 5,000 years and carried forward, without a perceptible 
break, into contemporary Shoshonean oral history. These emerging communities of ritual practice that once produced these incised stones are wholly masked in design grammars that merely classify motifs as "curvilinear" or "rectilinear," "bands" or "crosshatches."

\section{Incised Stones of the Intermountain Periphery}

Incised stone assemblages of the Intermountain West span seven states and seven millennia, defining a Central Shoshonean Core surrounded by an Intermountain Periphery-a huge C-shaped borderland extending more than $3,000 \mathrm{~km}$ (1,900 miles), encapsulating ethnohistoric territories of the Northern Paiute, Northern Shoshone, Eastern Shoshone, Ute, and Washo communities (Figure 3; Supplemental Tables 1 and 2). I can document fewer than 100 incised stones from the Intermountain Periphery, and virtually all are isolated finds (Supplementary Table 1). At this stage in the research, little can be said about these haphazardly scattered artifacts, except that they belong to a multimillennial, continent-wide tradition of Pan-American stone incising, perhaps with roots in global artifact traditions extending back 100,000 years (Lemke et al. 2015; Schuster and Carpenter 1988:796; Wernecke and Collins 2012). Based on available evidence, a significant relationship between the incised stones of the Intermountain Periphery and the prayerstone hypothesis cannot be demonstrated (but this could well change with more intensified research and consultation in the future).

\section{Incised Stones from the Central Shoshonean Core}

The Central Shoshonean Core contains $>3,300$ incised stones. Both their compositional styles and their tightly clustered distributions define multiple distinctive communities of ritual practice that emerged thousands of years ago and persisted among many Numic-speaking communities during ethnohistoric and contemporary times (Table 1; Figure 3). The prayerstone hypothesis proposes that many (perhaps most) of these incised stones are material manifestations of
Shoshonean epistemologies that can, perhaps, help "deepen our understanding of the changing social dynamics" of the ancient communities of practice that produced them (Cordell and HabichtMauche 2012:1)

\section{The Graptolite Summit Constellation}

More than 600 incised stones come from the Graptolite Summit Constellation in the Simpson Park, Toquima, and Monitor ranges of central Nevada (Figure 3; Supplemental Table 1). Accounting for nearly $20 \%$ of incised stones known from the entire Great Basin, this constellation is distributed among three dozen artifact clusters. Only $2 \%$ are isolated finds. The earliest date to Horizon 14 at Gatecliff Shelter (3690 $3600 \mathrm{cal} \mathrm{BC}$ ), and the most recent were found on a Western Shoshone house floor occupied $\sim$ AD 1800 (Tables 1 and 2). Their individual artifact itineraries reflect a votive relationship to their landscape.

Geological Creation and Selection. These incised stones are made almost exclusively of local Roberts Mountain limestone, dramatically exposed in thrust-faulted "geological windows" (Stewart and McKee 1977:16). Graptolite fossils are abundant here, their distinctive, shiny look standing out clearly against the dull matte limestone surface. Some appear as if they were drawn by pencil onto the rock surface (the name graptolite meaning, quite literally, "writing on the rock"). Modern fossil hunters flock to this place they call "Graptolite Summit" where they find a fossil type rarely seen outside of textbooks. For decades, professional paleontologists and avocational collectors alike have found thousands of identifiable fossils at this well-known spot.

Pilgrimages to Graptolite Summit are nothing new. The first foragers traversing Graptolite Summit stepped into a ritually preadapted landscape replete with thousands of eye-grabbing graptolite fossils gleaming from slab-like, platy limestone blanks littering the landscape. Native American travelers drawn to these extraordinary limestone exposures were facilitated (then as now) by the Pete's Summit trail, the best eastwest access through the northern Toquima Range. Shoshonean cosmology holds that some 
fossils possess a certain "personhood," reflecting their animate role as conduits of puha (Zedeño 2009:416), and the prayerstone hypothesis suggests that Graptolite Summit was recognized as a powerfully sacred place for millennia.

Enhancement and Empowerment. Although spanning a trajectory of more than 5,000 years, the Graptolite Summit incised stone assemblage remained remarkably homogeneous through time (T. Thomas 1983a:249-253; see Table 1). Created by a minimally subtractive technology, the natural edges of the original limestone blanks were left unmodified-not shaped, ground, flaked, pecked, polished, or perforated in any way. In this sense, they recall incised stones from the Gault site: "Wherever these objects are produced, the end product does not seem to have retained its importance, and, in fact, the process of manufacture and the patterns employed may have been more important than the decorated object after its initial use" (Wernecke and Collins 2012:669). But unlike Gault, many Graptolite Summit incised stones were used repeatedly, some with oil staining, surface polish, and frequent overmarking from different tools (despite plenty of blank space left on the same surface).

McKee and I (1972) postulated that many such "portable petroglyphs" were literal copies of local graptolite fossils. Some were barely "incised" at all, their surfaces modified instead by a distinctive "rocking" or "walking" movement of a double-tipped tool that produced sequences of "pivot points connected by 'legs' of crushed rock" (T. Thomas 1983a:251-252, Figures 106 and 107). This walked-rocker technique-evident in nearly one-quarter of the Graptolite Summit incised stones-undoubtedly reprises the ancient fossils populating the immediate area (see Figure 6, upper).

Mannequin model protocols are virtually absent at Graptolite Summit. Schuster, who personally examined many of these artifacts, dismissed the occasional mannequin motif as "abbreviations ... shorthand versions of more detailed, standardized designs. ... Apparently, details were remembered long after their logical positions have been forgotten" (Schuster and Carpenter 1988:911).

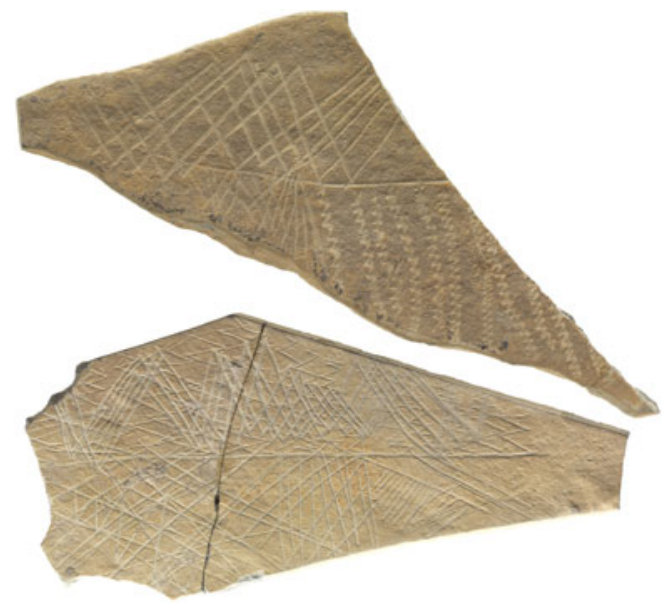

Figure 6. Two incised limestone artifacts from early Horizon 6 at Gatecliff Shelter (1550-1365 cal BC). On the uppermost stone, note the upper fields of crosshatching from the "walked-rocker" lines (see T. Thomas, 1983a: Figure 106); length is $17.4 \mathrm{~cm}$. At least three different cutting edges are evident on this artifact: (1) the doubletipped walked-rocker tool, (2) a thin, single-tipped tool, and (3) another single-tipped tool with a tiny gutter along the cutting edge, producing a double-edged incised track. Top: AMNH 20.3/6325; bottom: AMNH 20.3/ 2158-2159; length is $19.2 \mathrm{~cm}$ (courtesy of the American Museum of Natural History, photograph by Mourrice Papi).

Emplacement. McKee and I found a lone incised stone on the surface of Gatecliff Shelter (McKee and Thomas 1972:Figure 3), but subsequent excavations exposed a $12 \mathrm{~m}$ (40 ft) deep stratigraphic column that spanned 7,000 years and contained more than 400 incised limestone artifacts (D. Thomas 1983; Table 1). Although the incised stones at Graptolite Summit did not change much through time, the emplacement strategies certainly did. The logistic bighorn hunters who began the trajectory $\sim 3690-3600$ cal BC (Kennett et al. 2014; Table 2) eventually emplaced hundreds of these distinctive incised stones inside Gatecliff Shelter over the next 2,000 years. Once family bands took up residence here, they too left hundreds of incised stones, the most recent postdating cal AD 1400 —unquestionably linking the Graptolite Summit incised stone trajectory to ethnohistoric Western Shoshone communities.

The prayerstone hypothesis holds that these simple limestone artifacts were deliberately 
emplaced in "sacred places known to the people as places where power resides" (Fowler 2002:176)—effectively becoming "ceremonial trash" that passed through a gateway transcending the world of the mundane into the spiritual (Walker 1995:67). Shoshonean ritual cartography denotes numerous instances of those returning to a specific cave to pray for specific powers: some prayed for the power to become healers, others wished for success in hunting or gambling, still others wanted children, help protecting their families, or protection on a journey (Supplemental Table 3). Shoshonean epistemology requires that such spiritual favors be repaid, as with the pennies and beads left as votive offerings at Doctor Rock (Fowler 2002:Figure 111) conveying respect and thanks for help from a powerful place (Stoffle et al. 2004:38). Maybe this explains why 96 prayerstones were emplaced together more than 3,500 years ago at the rear of Gatecliff Shelter (D. Thomas 1983:491). Western Shoshoneans similarly emplaced 19 prayerstones in their 1880s wickiup at Grass Valley, likely the result of a healing ritual. Other Graptolite Summit prayerstones look like trailside votive offerings left in thanks for safe passage. Even when emplaced individually, over time, such prayerstones clustered nonrandomly across the landscape.

\section{The Ruby Cave Constellation}

Ruby Cave incised stones look very different from their Graptolite Summit counterparts (Ottenhoff 2015). Half were made of local slate and the rest were manufactured of Roberts Mountain limestone, imported from 40 to $80 \mathrm{~km}$ (25 to 50 miles) away. One-third of the Ruby Mountain incised stones clearly reflect Schuster's mannequin protocols (a high proportion unique within the Central Shoshonean Core; Table 1).

Despite such obvious visual differences, the Ruby Cave and Graptolite Summit incised stones reflect similar emplacement strategies, at least at first. The earliest prayerstones at Ruby Cave ( 2500-1500 cal BC) were left by bighorn hunting parties camping there-likely accompanying prayers for success on upcoming hunts or expressing gratitude for prayers already answered. Given its utter unsuitability for family residential use, Ruby Cave likely transitioned into a personal power place within the last two millennia - someplace to seek and maintain puha, to pray, or to request healing or luck in hunting or gambling.

\section{The Little Boulder Basin Constellation}

The 172 incised stones from the Little Boulder Basin define a wholly different constellation of ritual practice. Several are 2,000 years old, and many others were emplaced within the last 700 years, persisting into the contact period (Fenner 2013).

The Little Boulder Basin is immediately adjacent to Bootstrap Hill - the northernmost significant exposure of Roberts Mountain limestone containing exceptionally well-preserved silicified graptolite fossils (Merriam and McKee 1976:16). Foragers here completely ignored these obvious limestone exposures, choosing instead to inscribe the platy sedimentary stones found in local alluvial gravels. At least onequarter reflect Schuster's mannequin model, with motifs usually depicted as isolates (Table 1). The Little Boulder Basin incised stones were emplaced almost entirely in residential contexts, suggesting repeated curing episodes within domestic settings (like the Grass Valley incised stones during the 1880s).

\section{The Las Vegas Constellation}

The Las Vegas Constellation (Figures 3 and 7) lumps together $\sim 1,100$ incised stones from 28 distinct sites or clusters; future research will likely define multiple distinctive subconstellations of ritual practice. Lumped together for now, they demonstrate "organizational variations in the basic design system," with complex internal structuring and a preponderance of curvilinear motifs (T. Thomas 1983b:343; see also Klimowicz 1988:52, 62, 96-100, Table 3.4; Roberts 2017; Santini 1974:8). Schuster saw the fringed flap motif (a key element of his mannequin model) as diagnostic of the Las Vegas Constellation (Schuster and Carpenter 1988: 899-904).

All agree that the Las Vegas assemblages differ dramatically from incised stones elsewhere in the Great Basin. Radiocarbon-associated incised stones from Flaherty Rockshelter now 


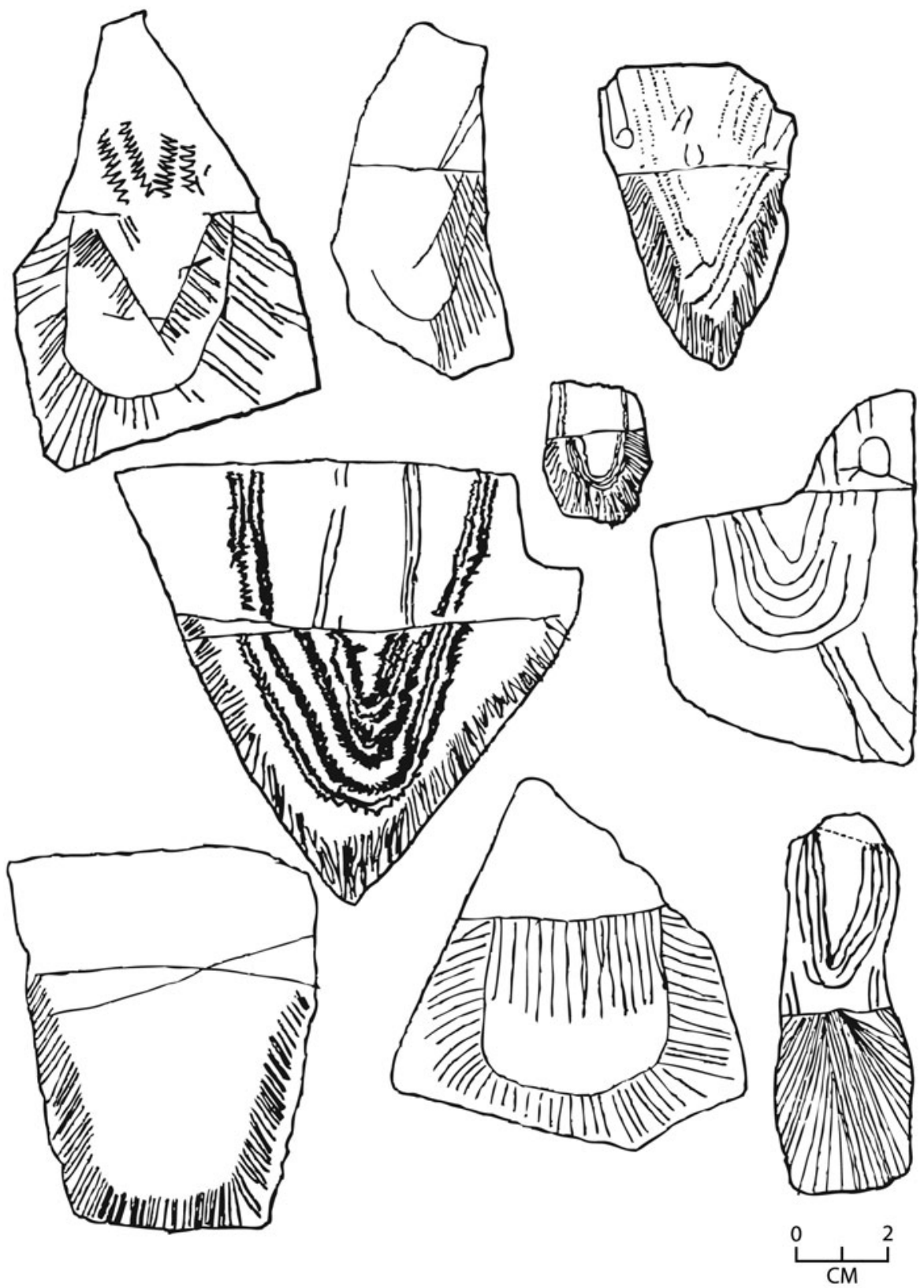

Figure 7. Incised sandstone artifacts from southern Nevada (after Klimowicz 1988:Figures 9, 10, and 11), each a variant of the fringed flap motif with similar variations on the horizontal divider and feather-like motifs. Whereas "most designs follow set compositions ... a few rearrange or simply 'assemble' basic elements ... merely shorthand versions of more detailed, standard designs” (Schuster and Carpenter 1988:912-913, Figures 847, 1044).

demonstrate the earliest-known fringed flap motif to $1500-650$ cal BC in southern Nevada (Figure 8; see also Supplemental Table 2). This same motif persisted locally into the eighteenth or nineteenth century AD, when Southern Paiute people emplaced an identically styled incised stone in Coyote Springs Rockshelter. Whatever its meaning, the foundational fringed flap motif persisted, apparently unchanged in composition and layout, for (at least) 3,000 years. 


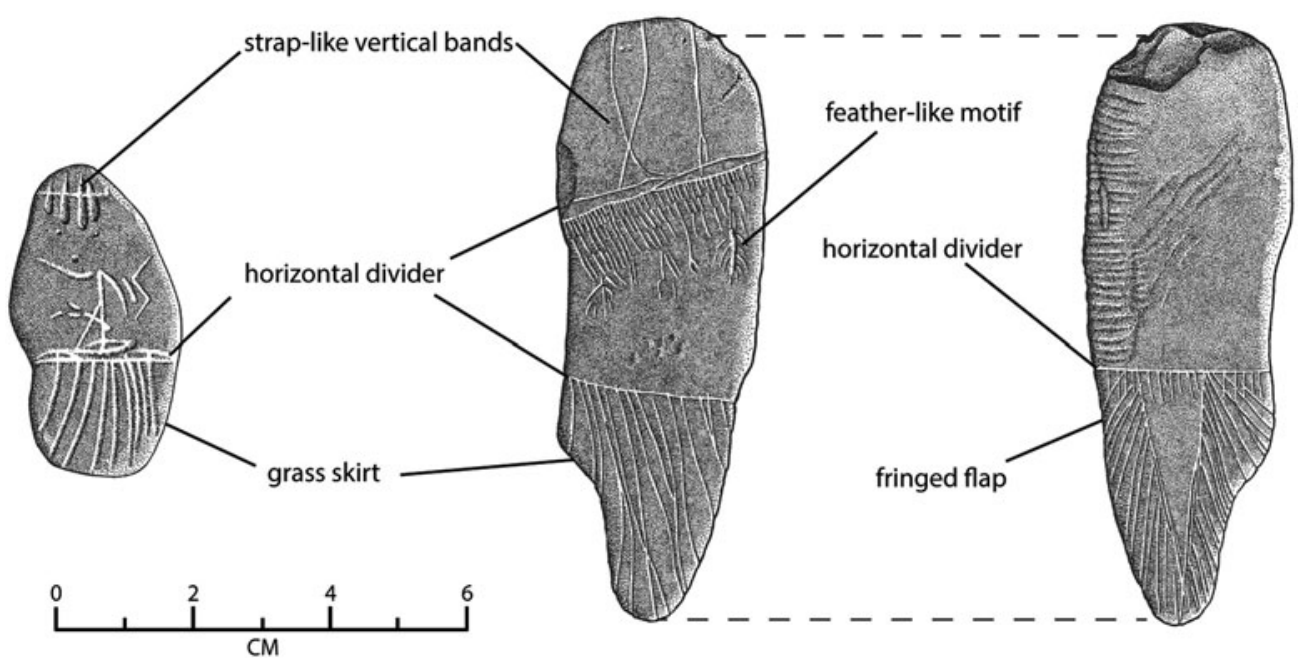

Figure 8. Two incised stones from Flaherty Cave, each with the mannequin overlay (after Blair and Wedding 2001; reproduced with permission). Left: 5-1153-69-1 correlates with a ${ }^{14} \mathrm{C}$ estimate of $1450-1090$ cal $\mathrm{BC}$; right: 5-1153-7064-1 (two sides) correlates with a ${ }^{14} \mathrm{C}$ estimate of 750-210 cal BC.

Almost half of the Las Vegas incised stones come from the Spring and Sheep ranges, with several emplaced inside local caves and rockshelters (Supplemental Table 1). This is hardly surprising, given that the prayerstone hypothesis reflects contemporary Southern Paiute epistemology linking incised stones to prayers and other spiritual activities carried out near Mount Charleston: "The Indian interpretation of these stones is that they are used in prayers" (Stoffle et al. 2004:116, Figure 5.8).

\section{The Archaic/Fremont/Shoshonean Cluster}

The 500-plus incised stones from the state of Utah tell a complex story beyond the present scope, but certain trends are significant for a broader understanding of Shoshonean constellations of practice (Supplemental Table 1). The Bonneville Basin has a spotty distribution of Archaic (pre-Fremont) incised stones emplaced in several caves and rockshelters-and hardly anyplace else. The earliest assemblages from Danger, Camels Back, and Hogup caves dating $\sim 5000-1500$ cal BC are small, but their proveniences are consistent with the hypothesized practice of emplacing votive prayerstones in known power places. Simms and Gohier (2010:87) suggest that these incised stones and local Archaic rock art largely consist of abstract designs representing "elements of a supernatural world that would carry forth into other, later styles ... shamanism, especially vision questing, hunting magic, and an animistic world in which spirits may harbor in plants, animals, objects and places."

Eastern Archaic basketry and incised stones transitioned directly into the Fremont complex, as apparently did Archaic people themselves (Adovasio et al. 2002:12). Incised stones diagnostic of the Great Salt Lake Fremont (Marwitt 1970:145) modified and amplified the ancestral Archaic patterning with the addition of mannequin-model elements prominently featured on Fremont incised stones (Figures 9 and 10; Table 1). The Fremont also augmented Archaic rock art with painted anthropomorphs and geometrics such as dots and ladders (and some elements also seen on ceramics) - creating an unmistakable Fremont tradition that conspicuously retained "ideological ties with the Great Basin peoples to the west [and] prevailed for several thousand years" (Schaafsma 1994:xii). Incised stones are found in post-Fremont contexts at various sites in northwestern Utah and southern Idaho.

\section{The Northern Inyo Cluster}

Something like 100 incised stones (mostly isolated finds) come from Inyo and Mono counties (southeastern California; Supplemental Table 1). 


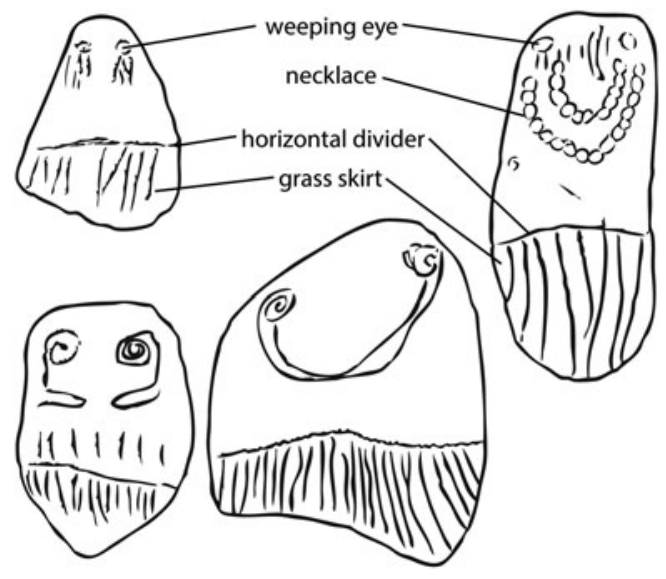

Figure 9. Fremont-style incised pebbles showing the weeping eye, horizontal divider, and grass skirt motifs (western Utah; after Schuster and Carpenter 1988:938938, Figure 1157; Warner 1981:Figure 3). Dimensions unavailable.

Most were found in the northern Inyo Mountains; the earlier sites were probably short-term hunting camps, and later occupations were likely fall or fall-and-winter piñon residential base camps (per Bettinger 1989). These incised stone assemblages are difficult to date (Supplemental Table 2), but the trajectory clearly carried over among the late nineteenth- or early twentieth-century Panamint Shoshone (Ritter 1980).

Relative to incised stones, pendants are extraordinarily common in the northern Inyo cluster. Bettinger has it right, concluding that these incised stones

differ from those that have been reported from central Nevada (e.g., McKee and Thomas 1972) in that they nearly always display some edge grinding in addition to incising. Presumably this reflects more careful curation of incised slates, perhaps as personal charm stones, in eastern California. In central Nevada, on the other hand, their importance may have been limited to individual magical or religious performances outside the immediate locational and temporal context of which they ceased to be of value [1989:78].

Although I believe that some northern Inyo incised stones were likely emplaced during healing rituals, the assemblage is sparse, and

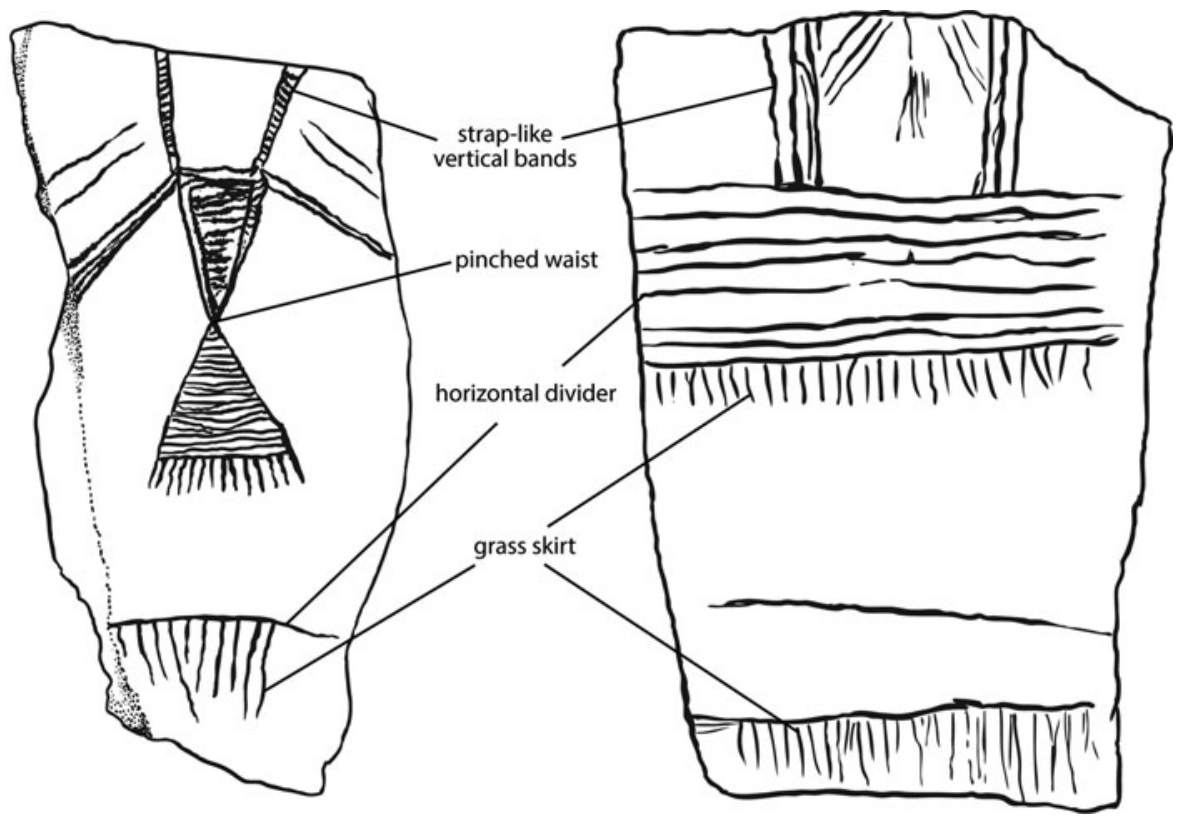

Figure 10. The mannequin model applied to two incised stones from Promontory Point, Utah (after Schuster and Carpenter 1988:942-943, Figures 1175-1176). Left: note the distinctive pinched-waist style characteristic of many Utah incised stones (Schuster and Carpenter 1988:911; see also Steward 1937:Figure 43/a). Length is 11.1 cm. Right: Natural History Museum of Utah, 19886. Length is $11.5 \mathrm{~cm}$. 
patterned associations with obvious power places is not convincing. Although this may change with further research, available data from northern Inyo provides little support for the prayerstone hypothesis, and these incised stones do not seem to belong to the Central Shoshonean core.

\section{Prayerstone Votive Practice}

The prayerstone hypothesis remains preliminary and requires further testing. The mannequin model was explored here, but additional finegrained heuristics are necessary to explore alternative compositional and elemental strategies. More intensive analysis will doubtless generate tighter chronological controls, likely leading to finer-grained site and constellation genealogies. Ongoing Native American consultations promise to help refine and (perhaps) redefine the preliminary constellations proposed here, possibly adding new ones as well.

That said, working from the results presented here, I conclude that the isolated incised stones of northern Inyo and the rest of the outer perimeter fail to support the prayerstone hypothesis. They lack the distinctive regional look so evident within the central Shoshonean core, and their largely scattered, atomized distributions impart little sense of repeated ritual practice. But these incised stones do convey themes and motifs. They have proveniences, but their object provenances remain to be delineated. It is perhaps premature to dismiss them as merely decorated rocks.

In stark contrast, the place logic and structural composition evident in the $>3,300$ incised stones from the central Shoshonean core is entirely consistent with the prayerstone hypothesis, reflecting what Fowler called "spiritual associations with their geography" (2002:180). To be sure, each prayerstone has a unique, personalized biography - picked up in a variety of places, they were selected for different qualities and marked in distinctive ways. Some were preplanned with complex designs, others only barely scratched. Some were carried around for a while. Some were decorated just once; others were repeatedly re-inscribed. But thousands of Shoshonean prayerstones share a fundamental, four-step itinerary-from geological genesis, to selection as potential ritualized paraphernalia, to enhancement and empowerment through a deliberate votive emplacement that was neither random nor haphazard.

Santini correctly perceived that the dense concentrations of incised stones around Las Vegas were clustered in distinctive ways, some apparently emplaced as a group: "if one were found there would be more" (1974: 13). The prayerstone hypothesis provides a relatively parsimonious explanation of these clusters - the common denominator being the perception of where puha resides and a shared belief in the "personhood" of prayerstones to serve as a conduit to that power (Zedeño 2009). This explains why so many incised stones turned up in the precise locales projected by Shoshonean place logicsome tucked individually into cracks deep inside caves, some left inside houses, and others piled up along the trails, by sacred springs, petroglyph panels, and dramatic rock outcrops.

Protocols embodied in the mannequin heuristic permit relatively fine-grained description and classification into constellations of ritual practice reflecting the enormous variability manifest in the thousands of incised stones from across the Intermountain West. Mannequin references are virtually absent in the $>600$ incised stones from Graptolite Summit but dominate prayerstone assemblages from Las Vegas and Fremont territory. Obscure mannequin derivatives (appearing as elemental isolates) characterize the Little Boulder Basin and Ruby Cave constellations. So too with the walked-rocker technique-uniquely employed to imitate local fossils at Graptolite Summit but used entirely differently than mannequin-style prayerstones of the eastern Archaic and Las Vegas constellations. Over five millennia, each regional constellation developed its own distinctive look, a trajectory defining a structured variability unquestionably associated with many (but not all) Numic-speaking populations.

So viewed, prayerstones are embodied cultural practice. Individual actions created each prayerstone, and distinctive constellations of votive practice emerging as cumulative outcomes of personal decision-making and epistemologies created biographies of each such artifact. People 
do not necessarily pray the same way-and to suggest otherwise homogenizes the very lives of those we wish to understand (Simms 1999:107108). The constellation trajectories came to differ from one another because local petitioners periodically innovated. If these innovations produced desired results, the votive practices may have been deemed acceptable by others, who in turn encouraged similar innovations and caused these new practices to persist. The distinctive regional clustering can be attributed to the constellations of ritual practice developed through the interactions of multiple communities who shared a belief in prayerful petitioning for puha and ritualized expressions of gratitude for favors granted.

\section{Prayerstones and Numic Language Distributions}

None of us would confuse the Graptolite Summit prayerstone assemblages with those from Las Vegas - they look very different, and they were ritually emplaced differently. Available archaeology demonstrates that this regionally diverse votive practice began 5,000 years ago in the central and southern Great Basin and persisted among many (but not all) ethnohistoric Numicspeaking communities.

Does the prayerstone hypothesis imply anything about the distribution of Numic languages? The prevailing hypothesis-still apparently accepted by a majority of practicing Great Basin anthropologists-posits a single, simultaneous, and late expansion of Numic-speaking Paviotso, Shoshone, and Ute communities across the Intermountain West, characterized by "dialectic differences ... so slight that one can only with the greatest difficulty imagine that they could have occupied the vast areas in which we find them for more than a very few centuries" (Lamb 1958:99). Evidence supporting the prayerstone hypothesis is consistent with major parts of Lamb's argument.

Archaeology, linguistics, and oral history have long suggested a collapse of the Lovelock culture and abandonment of Lahontan Basin before the Paviotso broke off from Mono speakers and moved northward into western Nevada (as summarized in Madsen and Rhode 1994).
The conspicuous absence of prayerstones in Paviotso territory reflects both unsuitable local geology and the fact that Penutian-speaking Lovelock communities did not make incised stones. Because votive prayerstones barely caught on in southeastern California, it is hardly surprising that the northward immigrants did not bring the practice with them. Although Northern Paiute cosmology involves considerable votive ritual in sacred places where power resides, there is no record (ethnographically or archaeologically) of incised stones as prayerful offerings (Fowler 2002:171, 177-178; Park in Fowler 1989; Supplemental Table 1).

Eastern Great Basin archaeology is also largely consistent with Lamb's (1958) hypothesis (Rhode and Madsen 1994). Multiple Archaic and Fremont communities emplaced prayerstones in the same caves and rockshelters (Supplemental Table 1). If individual males were largely responsible for the initial inmigration of farmers into Fremont territory (Simms 2008:199-209; Simms and Gohier 2010:73), then perhaps already-resident females were responsible for carrying over Archaic prayerstone and rock art practices into Fremont communities.

Steward included "etched stones" as a significant element in his definition of Promontory culture $(1937: 77-79,86,122)$, and the mannequin motifs on Figure 10 raise intriguing issues regarding Fremont-Promontory relationships. Recent reanalysis and re-excavation suggests that late Fremont peoples-particularly women -became incorporated in the Athabascanspeaking Promontory cave population (Yanicki and Ives 2017). If they brought with them Fremont ceramic, basketry, and incised stone practices, this ethnogenetic turn may account for the imitations of northern Plains garments made in the Fremont style (as in Figure 10, left; see also Ortman and McNeil 2017).

The demise of Fremont farming ( cal AD 1280-1460) may have led to a coalescing of indigenous and immigrant populations, with some moving elsewhere and others persisting as foragers (Madsen and Simms 1998:314-317). Although Fremont basketry and ceramics are wholly dissimilar from subsequent Shoshonean counterparts (Adovasio et al. 2002:21; Simms 
2008:248-255), incised stones turn up in postFremont contexts at Hogup Cave, Thomas Shelter, Spotten Cave, and Trapper Cliff Shelter. Perhaps they were emplaced by carryover Fremont foragers, or maybe the practice was (re)introduced by newly arrived Numic communities. Both alternatives are consistent with Lamb's (1958) hypothesis.

Problems arise in the Central Shoshonean core. If Lamb's (1958) pan-Great Basin hypothesis is correct, how could the forebears of Western Shoshone and Southern Paiute ancestral communities have participated in Shoshonean cosmological practices spanning multiple millennia if they only arrived in central and southern Nevada a few hundred years ago? Does prayerstone evidence reflect an ethnogenetic Shoshonean continuity across the millennia? Or are there explanations of how such material manifestations of deep cosmology could be picked up by unrelated newcomers?

One hypothesis would extend the Fremont/ Promontory scenario westward to suggest that migrating Numic speakers adopted wholesale an ancient prayerstone practice upon arrival in the central and southern Great Basin. Maybe the newcomers incorporated still-resident nonNumics into their communities. Or perhaps arriving Numic speakers could recognize in their new landscapes former places of power and understand that the now-archaeological prayerstones emplaced nearby once served as conduits to that puha-basically applying their own cultural logic to adapt previous votive practice as their own. Both scenarios are consistent with Lamb's (1958) hypothesis.

Admitting some personal discomfort with such cosmological makeovers, I favor an alternative hypothesis: distinctively Shoshonean prayerstone rituals originated $\sim 5,000$ years ago in the central and southern Great Basin, and some communities of practice carried this votive ritual forward into the ethnohistoric period. I think these continuities are amply demonstrated in the long-term, regionalized compositional trajectories and the individual emplacement practices across the millennia. Available prayerstone evidence fails to support a post-AD Numic arrival in the central or southern Great Basinno perceivable breaks in prayerstone practices, no former constellations terminated, and no new constellations begun within the last 1,000 years. I think ancient incised stone genealogies support an ancient Shoshonean presence within the central Intermountain West-but not in Lamb's classic "Numic heartland" near Death Valley (Aikens and Witherspoon 1986; Grayson 1994; Holmer 1994; Thomas 2014:142).

\section{Theoretical Pluralism and Shoshonean Ethnogenesis}

Each of these multiple working hypothesesthose supporting Lamb's (1958) Numic expansion and its competitors-is framed by analogies to ethnographic groups descending from a common ancestor. Such population histories invoking migration and/or in situ demographic expansion typically reflect an intertwining of genes, language, and behavior within a single cladistic tree "with ethnic groups in this phylogenetic unit as the leaves, and population events such as migrations being the branches" (Ortman 2012:32).

I am reminded of Simms's (1994) call for an "unpacking" of the Numic spread debate, but that has not happened. Conversations are still constrained by bounded taxonomic conventions that set the agenda - theoretically, spatially, and temporally. Criticizing a preoccupation with such "metaphors of boundedness," Simms argued that epistemological abstractions such as "European history," "Hopi history," and "the Numic spread" have long tyrannized archaeologists and historians into transforming "dynamic interconnected phenomena into static, disconnected things" (1999:105-107). This is why hypotheses about the Numic spread (by Lamb and the others) share the assumption that genes, language, and culture necessarily evolved "as a package in bounded social groups" (Ortman 2012:2).

While certainly not precluding possibilities of past migrations, such "unpacking" would enable the tracking of an ethnic group's genetic, linguistic, and cultural heritage without the assumption of specific, parallel descent. The concept of "ethnogenesis" elevates the focus away from entire "peoples" to open up possibilities that "human beings [create] novel and new cultures and societies by combining bits and pieces of pre-existing cultures in a free and enterprising 
manner" (Moore 1996:30; see also Ortman 2012:32; Weik 2014). Such ethnogenic communities would sometimes lack close interactive correlations among language, biology, and culture-there conforming to anthropology's foundational premise that (1) these three variables do not necessarily coevolve as packages, and (2) they should instead be analyzed as potentially independent variables (Barth 1969; Boas 1904; Gregory and Wilcox 2015; Ortman 2012:32; Rhode and Madsen 1994:220; Stojanowski 2010:48, 50, Table 1, 2013:7).

More productive pursuit of Shoshonean ethnogenesis will benefit from melding innovative ways to expand already-productive "gastric" strategies with a simultaneous exploration of practice theories capable of blurring the boundaries of conventionally imposed community identities. This enhanced theoretical pluralism could even trigger a parallel exploration of cultural pluralism in the past-one capable of recognizing that the emergence of new, hybrid communities through the organization of daily life - and free from the assumption of "monolithic clashes of categories per se" (Simms 1999:106; see also Lightfoot et al. 1998). In this way, anthropological perceptions of identity could increasingly be perceived as situational, relational, and subject to negotiation (Hu 2013).

This is why, within the spirit of theoretical pluralism, I propose prayerstones not as "ethnic markers" of Numic languages or Shoshonean identity, but rather as another potential avenue for teasing out "the social life of things" (Appadurai 1986). So viewed, the diversity and antiquity of these long-term constellations of votive prayerstone practice suggest dramatically more complex cultural trajectories than implied by Lamb's widely accepted model of a single, late, simultaneous Numic spread across the Great Basin.

\section{Notes}

1. My use of the term "Shoshonean" parallels Julian Steward (1938, 1955:101, 1970:116-117) in denoting the Numic-speaking Ute, Eastern Shoshone, Northern Shoshone, Western Shoshone, Northern Paiute, Southern Paiute, and Chemehuevi people of western Colorado, Utah, southwestern Wyoming, southern Utah, Nevada, eastern Oregon, and southeastern California. Consultation is presently ongoing with numerous consultants from each of these tribes regarding their beliefs about the prayerstone hypothesis and whether the conventional covering term "Shoshonean" remains appropriate today.

2. Since this was written, more than 6,000 incised and painted stones have been found at Parpalló Cave (Spain); large collections are also known from elsewhere in Spain, France, and Germany (García et al. 2016).

3. I am aware of only one other attempt to apply artifact itinerary perspectives to incised stone use and manufacturethe Lillios (2008) and Lillios and Thomas (2010) analyses of Late Neolithic engraved slate plaques from Iberia (which would not be considered incised stones in the definition employed here).

Acknowledgments. I thank Tom Blaber, Mourrice Papi, Diana Rosenthal-Roberson, Anna Semon, Nick Triozzi, Lorann P. Thomas, and Kayla Younkin for assistance in preparing this manuscript. I am grateful to María Nieves Zedeño for providing the Spanish translation of the abstract. Thanks also to several others who helped me round up the incised stones for this study (each individually acknowledged in Supplemental Table 1). I am particularly grateful to several friends and colleagues for comments on earlier drafts of this paper: Richard Arnold, Pat Barker, Elliot Blair, Michael Delacorte, Alan Garfinkel, Dayna Giambastiani, Mark Giambastiani, John Ives, Joel Janetski, Bill Hildebrandt, Kent Lightfoot, David Madsen, Kelly McGuire, Christopher Morgan, Steven Simms, Helen Wells, Gabriel Yanicki, David Yoder, María Nieves Zedeño, and an anonymous reviewer.

Data Availability Statement. Data used as the basis for this analysis are included in the supplementary data files.

Supplementary Materials. Supplementary materials are linked to the online version of this article, which is accessible via the Society for American Archaeology member log-in at https://doi.org/10.1017/aaq.2018.73

Supplemental Table 1. Incised Stones in Great Basin Contexts.

Supplemental Table 2. Incised Stones from Datable Contexts.

Supplemental Table 3. A Ritualized Shoshonean Cartography of Nevada Cultural Landscapes.

Supplemental References.

\section{References Cited}

Adovasio, James M., David R. Pedler, and Jeff S. Illingworth 2002 Fremont Basketry. Utah Archaeology 15:5-26.

Aikens, C. Melvin

1970 Hogup Cave. University of Utah Anthropological Papers No. 93. University of Utah Press, Salt Lake City.

Aikens, C. Melvin, and Younger T. Witherspoon

1986 Great Basin Numic Prehistory: Linguistics, Archaeology, and Environment. In Anthropology of the Desert West: Essays in Honor of Jesse D. Jennings, edited by Carol J. Condie and Don D. Fowler, pp. 7-20. University of Utah Anthropological Papers No. 110. University of Utah Press, Salt Lake City.

Appadurai, Arjun (editor)

1986 The Social Life of Things: Commodities in Cultural Perspective. Cambridge University Press, Cambridge. 
Arnold, Richard, and Richard W. Stoffle

2006 Puha Path to Black Mountain. Paper presented at the 30th Great Basin Anthropological Conference, Las Vegas, Nevada.

Barth, Fredrick

1969 Introduction. In Ethnic Groups and Boundaries: The Social Organization of Culture Difference, edited by Fredrick Barth, pp. 9-38. Little, Brown, Boston.

Basso, Keith

1996 Wisdom Sites in Places: Landscape and Language Among the Western Apache. University of New Mexico Press, Albuquerque.

Bettinger, Robert L.

1989 The Archaeology of Pinyon House, Two Eagles, and Crater Middens: Three Residential Sites in Owens Valley, Eastern California. Anthropological Papers Vol. 67. American Museum of Natural History, New York. http:// hdl.handle.net/2246/250, accessed October 26, 2018.

Blair, Lynda M., and Jeffrey R. Wedding

2001 Archaeological Excavations for the Apex Land Exchange, Clark County, Nevada, Vol. 1, Rockshelters $26 C K 415$, 26CK3780, and 26CK4415. Bureau of Land Management Report No. 5-2377(P). Report No. 5-164-13. Harry Reid Center for Environmental Studies, University of Nevada, Las Vegas.

Boas, Franz

1904 The History of Anthropology. Science, n.s., 20:513-524.

Brown, Linda A., and William H. Walker

2008 Prologue: Archaeology, Animism, and Non-human Agents. Journal of Archaeological Method and Theory 15:297-299.

Budy, Elizabeth E.

1987 Incised Tablets and Polished Stones. In Archaeological Investigations at Panaca Summit, edited by Robert G. Elston and Kenneth E. Juell, pp. 79-104. Cultural Resource Series No. 10. Bureau of Land Management, Reno, Nevada.

Cannon, Michael D.

2010 A Revised Research Context for the Prehistoric Archaeology of the Little Boulder Basin Area, Northcentral Nevada. BLM Nevada Cultural Resource Series 21. Bureau of Land Management, Reno.

Carroll, Alex K., Maria Nieves Zedeño, and Richard W. Stoffle

2004 Landscapes of the Ghost Dance: A Cartography of Numic Ritual. Journal of Archaeological Method and Theory 11:127-156.

Cordell, Linda S., and Judith A. Habicht-Mauche

2012 Practice Theory and Social Dynamics Among Prehistoric and Colonial Communities in the American Southwest. In Potters and Communities of Practice: Glaze Paint and Polychrome Pottery in the American Southwest, AD 1250-1700, edited by Linda S. Cordell and Judith A. Habicht-Mauche, pp. 1-7. Anthropological Papers of the University of Arizona No. 75. University of Arizona Press, Tucson.

d'Errico, Francesco, Christopher Henshilwood, Graeme Lawson, Marian Vanhaeren, Anne-Marie Tillier, Marie Soressi, Frédérique Bresson, Bruno Maureille, April Nowell, Joseba Lakarra, Lucinda Backwell, and Michèle Julien

2003 Archaeological Evidence for the Emergence of Language, Symbolism, and Music: An Alternative Multidisciplinary Perspective. Journal of World Prehistory 17:1-70.
Dixon, Raoul M.

1987 Way of the Hunters: An Illustrated Commentary and Prehistoric Record. Carlton Press, New York.

Fenner, Lindsay

2013 Portable Rock Art in the Little Boulder Basin Area. In Data Recovery at 25 Prehistoric Archaeological Sites in the Dee Arturo Project Area, Elko County, Nevada, edited by Michael D. Cannon, Stephanie Lechert, Sarah Creer, and Jesse Adams, pp. 2-214. Report prepared for Barrick Gold Exploration Inc. Submitted to Bureau of Land Management, Elko District, Tuscarora Field Office, Nevada. BLM Project No. 1-2811. SWCA Report 201.

Fowler, Catherine $\mathrm{S}$.

2002 In the Shadow of Fox Peak: An Ethnography of the Cattail-Eater Northern Paiute People of Stillwater Marsh. Nevada Humanities Committee, Reno.

Fowler, Catherine S. (editor)

1989 Willard Z. Park's Ethnographic Notes on the Northern Paiute of Western Nevada, 1933-1944. University of Utah Anthropological Papers No. 114. University of Utah Press, Salt Lake City.

Fowler, Don D., and Catherine S. Fowler (editors)

1971 Anthropology of the Numa: John Wesley Powell's Manuscripts on the Numic Peoples of Western North America, 1868-1880. Contributions to Anthropology No. 14. Smithsonian Institution, Washington, DC.

García, Clodoaldo Roldán, Valentín Villaverde Bonilla, Isabel Ródenas Marín, and Sonia Murcia Mascarós

2016 A Unique Collection of Palaeolithic Painted Portable Art: Characterization of Red and Yellow Pigments from the Parpalló Cave (Spain). PLoS ONE 11(10):e0163565. https://doi.org/10.1371/journal.pone. 0163565, accessed October 12, 2018.

Grayson, Donald K

1994 Chronology, Glottochronology, and Numic Expansion. In Across the West: Human Population Movement and the Expansion of the Numa, edited by David B. Madsen and David Rhode, pp. 20-23. University of Utah Press, Salt Lake City.

Green, Dee F

1964 The Hinckley Figurines as Indicators of the Position of Utah Valley in the Sevier Culture. American Antiquity 30:74-80.

Gregory, David A., and David R. Wilcox (editors)

2015 Zuni Origins: Toward a New Synthesis of Southwestern Archaeology. University of Arizona Press, Tucson.

Hahn, Hans P., and Hadas Weiss

2013 Introduction: Biographies, Travels and Itineraries of Things. In Mobility, Meaning and the Transformation of Things, edited by Hans P. Hahn and Hadas Weiss, pp. 114. Oxbow Books, Oxford.

Holmer, Richard N.

1994 In Search of the Ancestral Northern Shoshone. In Across the West: Human Population Movement and the Expansion of the Numa, edited by David B. Madsen and David Rhode, pp. 179-187. University of Utah Press, Salt Lake City.

$\mathrm{Hu}, \mathrm{Di}$

2013 Approaches to the Archaeology of Ethnogenesis: Past and Emergent Perspectives. Journal of Archaeological Research 21:371-402.

Hunt, Alice

1960 Archaeology of the Death Valley Salt Pan. University of Utah Anthropological Papers No. 47. University of Utah Press, Salt Lake City. 
Joordens, Josephine C. A., Francesco d'Errico, Frank P. Wesselingh, Stephen Munro, John de Vos, Jakob Wallinga, Christina Ankjærgaard, Tony Reimann, Jan R. Wijbrans, Klaudia F. Kuiper, Herman J. Mücher, Hélène Coqueugniot, Vincent Prié, Ineke Joosten, Bertil van Os, Anne S. Schulp, Michel Panuel, Victoria van der Haas, Wim Lustenhouwer, John J. G. Reijmer, and Wil Roebroeks 2015 Homo Erectus at Trinil on Java Used Shells for Tool Production and Engraving. Nature 518:228-231.

Joyce, Rosemary A.

2000 Heirlooms and Houses: Materiality and Social Memory. In Beyond Kinship: Social and Material Reproduction in House Societies, edited by Rosemary A. Joyce and Susan D. Gillespie, pp. 189-212. University of Pennsylvania Press, Philadelphia.

2012 Thinking about Pottery Production as Community Practice. In Potters and Communities of Practice: Glaze Paint and Polychrome Pottery in the American Southwest, AD 1250-1700, edited by Linda S. Cordell and Judith A. Habicht-Mauche, pp. 149-254. Anthropological Papers of the University of Arizona No. 75. University of Arizona Press, Tucson.

Joyce, Rosemary A., and Susan D. Gillespie (editors)

2015 Things in Motion: Object Itineraries in Anthropological Practice. School for Advanced Research Press, Santa Fe, New Mexico.

Kelly, Robert L.

1999 Thinking about Prehistory. In Models for the Millennium: Great Basin Anthropology Today, edited by Charlotte Beck, pp. 111-117. University of Utah Press, Salt Lake City.

Kennett, Douglas K., Brendan J. Culleton, Jaime Dexter, Scott A. Mensing, and David Hurst Thomas

2014 High-Precision AMS ${ }^{14} \mathrm{C}$ Chronology for Gatecliff Shelter, Nevada. Journal of Archaeological Science 52:621-632.

Klimowicz, Janis R.

1988 A Structural Analysis of Prehistoric Incised Stones from Southern Nevada. Master's thesis, Department of Anthropology, University of Nevada, Reno.

Kopytoff, Igor

1986 The Cultural Biography of Things: Commoditization as Process. In The Social Life of Things: Commodities in Cultural Perspective, edited by Arjun Appadurai, pp. 64-91. Cambridge University Press, Cambridge.

Lamb, Sidney M.

1958 Linguistic Prehistory of the Great Basin. International Journal of American Linguistics 25:95-100.

Lemke, Ashley K., Daniel C. Wernecke, and Michael B. Collins

2015 Early Art in North America: Clovis and Later Paleoindian Incised Artifacts from the Gault Site, Texas (41BL323). American Antiquity 80:113-133.

Lenik, Edward J.

2016 Amulets, Effigies, Fetishes, and Charms: Native American Artifacts and Spirit Stones from the Northeast. University of Alabama Press, Tuscaloosa.

Liljeblad, Sven

1986 Oral Tradition: Content and Style of Verbal Arts. In Great Basin, edited by Warren L. d'Azevedo, pp. 641659. Handbook of North American Indians, Vol. 11, William C. Sturtevant, general editor, Smithsonian Institution, Washington, DC.

Lillios, Katina

2008 Heraldry for the Dead: Memory, Identity, and the
Engraved Stone Plaques of Neolithic Iberia. University of Texas Press, Austin.

Lillios, Katina, and Jonathan Thomas

2010 Speaking of Stone, Speaking through Stone: An Exegesis of an Engraved Slate Plaque from Late Neolithic Iberia. In Materialitas: Working Stone, Carving Identity, edited by Blaze O'Connor, Gabriel Cooney, and John Chapman, pp. 138-146. Oxford Books, Oxford.

Lightfoot, Kent G., Antoinette Martinez, and Ann M. Schiff 1998 Daily Practice and Material Culture in Pluralistic Social Settings: An Archaeological Study of Culture Change and Persistence from Fort Ross, California. American Antiquity 63:199-222.

Lowie, Robert $\mathrm{H}$

1924 Shoshonean Tales. Journal of American Folklore 37 (143-144):1-242.

Madsen, David B., and David Rhode (editors)

1994 Across the West: Human Population Movement and the Expansion of the Numa. University of Utah Press, Salt Lake City.

Madsen, David B., and Steven R. Simms

1998 The Fremont Complex: A Behavioral Perspective. Journal of World Prehistory 12:255-336.

Marshack, Alexander

1972a The Roots of Civilization. McGraw-Hill, New York.

1972b Upper Paleolithic Notation and Symbol. Science 178:817-828.

Marwitt, John P.

1970 Median Village and Fremont Culture Regional Variation. University of Utah Anthropological Papers No. 95. University of Utah Press, Salt Lake City.

McGuire, Kelly R., and William R. Hildebrandt

2017 Style, Identity, and Resource Competition on the Border: The Incised Stones of the Sacramento River Canyon. Quaternary International. https://doi. org/10.1016/j.quaint.2017.12.024, accessed October 26, 2018.

McKee, Edwin H., and David Hurst Thomas

1972 Petroglyph Slabs from Central Nevada. Plateau 44(3):85-104.

Merriam, Charles W., and Edwin H. McKee

1976 The Roberts Mountains Formation: A Regional Stratigraphic Study with Emphasis on Rugose Coral Distribution. US Geological Survey Professional Paper No. 973. US Government Printing Office, Washington, DC.

Miller, Daniel

1998 Why Some Things Matter. In Material Cultures: Why Some Things Matter, edited by Daniel Miller, pp. 3-21. University of Chicago Press, Chicago.

Miller, Jay

1983 Basin Religion and Theology: A Comparative Study of Power (Puha). Journal of California and Great Basin Anthropology 5:66-86.

Moore, John H.

1996 The Cheyenne. Blackwell, Malden, Massachusetts.

Morgan, Chris, Robert L. Bettinger, and Mark Giambastiani

2014 Aboriginal Alpine Ceremonialism in the White Mountains, California. Journal of California and Great Basin Anthropology 34:153-171.

O'Meara, Sean

2014 Prayer Stones: Incised Stones and the Continuity of Southern Paiute Ceremony. Paper presented at the 34th Great Basin Anthropological Conference, Boise, Idaho. 
Ortman, Scott G.

2012 Winds from the North: Tewa Origins and Historical Anthropology. University of Utah Press, Salt Lake City.

Ortman, Scott G., and Lynda D. McNeil

2017 The Kiowa Odyssey: Evidence of Historical Relationships among Pueblo, Fremont, and Northwest Plains Peoples. Plains Anthropologist 63(245):152-174.

Osborne, Robin

2004 Hoards, Votives, Offerings: The Archaeology of the Dedicated Object. World Archaeology 36:1-10.

Ottenhoff, Randall

2015 Incised Stones of the Great Basin: A Contextual Analysis. PhD dissertation, School of Forensics and Applied Science, University of Central Lancashire, Preston, England.

Park, Willard C.

1938 Shamanism in Western North America: A Study of Cultural Relationships. Studies in the Social Sciences No. 2. Northwestern University, Evanston, Illinois.

Pauketat, Timothy A.

2013 An Archaeology of the Cosmos: Rethinking Agency and Religion in Ancient America. Routledge, Abingdon, England.

Rhode, David, and David B. Madsen

1994 Where Are We? In Across the West: Human Population Movement and the Expansion of the Numa, edited by David B. Madsen and David Rhode, pp. 213-222. University of Utah Press, Salt Lake City.

Ritter, Eric W.

1980 A Historic Aboriginal Structure and Its Associations, Panamint Mountains, California. Journal of California and Great Basin Anthropology 2:97-113.

Roberts, Heidi

2017 It's Complicated: Discerning the Post-Puebloan Period in Southern Nevada's Archaeological Record. In Fierce and Indomitable: The Protohistoric Non-Pueblo World in the American Southwest, edited by Deni J. Seymour, pp. 281-300. University of Utah Press, Salt Lake City.

Santini, James

1974 A Preliminary Report on the Analysis of Incised Stones from Southern Nevada. Nevada Archaeologist 2(1):4-15.

Schaafsma, Polly

1994 The Rock Art of Utah. University of Utah Press, Salt Lake City.

Schuster, Carl

1968 Incised Stones from Nevada and Elsewhere. Nevada Archaeological Survey Reporter 2(5):4-23.

Schuster, Carl, and Edward Snow Carpenter

1988 Materials for the Study of Social Symbolism in Ancient and Tribal Art: Based on the Research and Writings of Carl Schuster. 3 Volumes. Vol. 2: Family Tree. Book 4: 23 Great Basin. Rock Foundation, Dallas, Texas.

1996 Patterns That Connect: Social Symbolism in Ancient \& Tribal Art. Harry N. Abrams, New York.

Simms, Steven R.

1994 Unpacking the Numic Spread. In Across the West: Human Population Movement and the Expansion of the Numa, edited by David B. Madsen and David Rhode, pp. 76-81. University of Utah Press, Salt Lake City.

1999 Chasing the Will-o'-the-Wisp of Social Order. In Models for the Millennium: Great Basin Anthropology Today, edited by Charlotte Beck, pp. 105-110. University of Utah Press, Salt Lake City.
2008 Ancient Peoples of the Great Basin and Colorado Plateau. Left Coast Press, Walnut Creek, California.

Simms, Steven R., and François Gohier

2010 Traces of Fremont: Society and Rock Art in Ancient Utah. University of Utah Press, Salt Lake City.

Steward, Julian H.

1933 Ethnography of the Owens Valley Paiute. University of California Publications in American Archaeology and Ethnology No. 33:233-350. University of California Press, Berkeley.

1937 Ancient Caves of the Great Salt Lake Region. Bureau of American Ethnology Bulletin No. 116. Smithsonian Institution, Washington, DC.

1938 Basin Plateau Aboriginal Sociopolitical Groups. Bureau of American Ethnology Bulletin No. 120 Smithsonian Institution, Washington, DC.

1955 Theory of Culture Change. University of Illinois Press, Urbana.

1970 The Foundations of Great Basin-Plateau Shoshonean Society. In Languages and Cultures of Western North America: Essays in Honor of Sven S. Liljeblad, edited by Earl H. Swanson , Jr., pp. 113-151. Idaho State University Press, Pocatello.

Stewart, John H., and Edwin H. McKee

1977 Part I, Geology. In Geology and Mineral Deposits of Lander County, Nevada. Nevada Bureau of Mines and Geology Bulletin No. 88:1-59.

Stoffle, Richard W., Fletcher Chmara-Huff, Kathleen Van Vlack, and Rebecca Toupal

2004 Puha Flows from It: The Cultural Landscape Study of the Spring Mountains. Report prepared for the U.S. Forest Service. Bureau of Applied Research in Anthropology, University of Arizona, Tucson.

Stoffle, Richard W., Rebecca S. Toupal, Kathleen Van Vlack, and Richard Arnold (editors)

2005 PU-Nav-Kai-Vi, Duepeth Tavave. Vol. 1. Black Mountain Ethnographic Summary. Prepared for Nellis Air Force Base and Range Complex, Nevada Test and Training Range. Bureau of Applied Research in Anthropology, University of Arizona, Tucson.

Stoffle, Richard W., Kathleen A. Van Vlack, Rebecca S. Toupal, Sean M. O’Meara, Jessica L. MedwiedSavage, Henry F. Dobyns, and Richard W. Arnold

2008 American Indians and the Old Spanish Trail. Report prepared for the U.S. National Park Service. Bureau of Applied Research in Anthropology, University of Arizona, Tucson.

Stoffle, Richard W., and Maria Nieves Zedeño

2001 Historic Memory and Ethnographic Perspectives on the Southern Paiute Homeland. Journal of California and Great Basin Anthropology 23:229-248.

Stoffle, Richard W., Maria Nieves Zedeño, and David B. Halmo (editors)

2000 American Indians and the Nevada Test Site: A Model of Research and Consultation. U.S. Government Printing Office, Washington, DC.

Stojanowski, Christopher M.

2010 Bioarchaeology of Ethnogenesis in the Colonial Southeast. University of Florida Press, Gainesville.

2013 Mission Cemeteries, Mission Peoples: Historical and Evolutionary Dimensions of Intracemetery Bioarchaeology in Spanish Florida. University of Florida Press, Gainesville.

Thomas, David Hurst

1983 The Archaeology of Monitor Valley: 2. Gatecliff Shelter. Anthropological Papers Vol. 58, No. 1. 
American Museum of Natural History, New York. http:// digitallibrary.amnh.org/handle/2246/267, accessed October 26, 2018.

2014 Exploring and Explaining Alta Toquima: The Higher You Get, the Higher You Get. SAA Archaeological Record 14(3):32-37.

Thomas, Trudy

1983a Material Culture of Gatecliff Shelter: Incised Stones. In The Archaeology of Monitor Valley: 2. Gatecliff Shelter, by David Hurst Thomas, pp. 246-278. Anthropological Papers Vol. 59, No. 1. American Museum of Natural History, New York.

1983b The Visual Symbolism of Gatecliff Shelter. In The Archaeology of Monitor Valley: 2. Gatecliff Shelter, by David Hurst Thomas, pp. 332-352. Anthropological Papers Vol. 59, No. 1. American Museum of Natural History, New York.

Tuohy, Donald R.

1986 Portable Art Objects. In Great Basin, edited by Warren L. d'Azevedo, pp. 277-237. Handbook of North American Indians, Vol. 11, William C. Sturtevant, general editor, Smithsonian Institution, Washington, DC.

Vander, Judith

1997 Shoshone Ghost Dance Religion: Poetry Songs and Great Basin Context. University of Chicago Press, Urbana, Illinois.

Van Vlack, Kathleen

2018 Puha Po to Kavaicuwac: A Southern Paiute Pilgrimage in Southern Utah. International Journal of Intangible Heritage 13:130-141.

Wadley, Lyn

2012 Revisiting Late Stone Age Collections from Big Elephant Shelter, Namibia. South African Archaeological Bulletin 67(195):101-107.

Walker, William $\mathrm{H}$.

1995 Ceremonial Trash. In Expanding Archaeology, edited by James M. Skibo, William H. Walker, and Axel E. Nielsen, pp. 67-79. University of Utah Press, Salt Lake City.

Walker, William H., and Lisa J. Lucero

2000 The Depositional History of Ritual and Power. In Agency in Archaeology, edited by Marcia-
Anne Dobres and John E. Robb, pp. 130-147. Routledge Press, London.

Warner, Jesse

1981 Engraved Pebble Style from of the Salt Flats of Western Utah. American Rock Art Research Association Newsletter 6:88-102.

Weik, Terrance M.

2014 The Archaeology of Ethnogenesis. Annual Review of Anthropology 43:291-305.

Wernecke, D. Clark, and Michael B. Collins

2012 Patterns and Process: Some Thoughts on the Incised Stones from the Gault Site, Central Texas, United States. In L'Art Pléistocène dans le Monde: Actes du Congres IFRAO 2010, edited by Jean Clottes, pp. 120-121. Préhistoire, Art et Sociétés: Bulletin de la Société Préhistorique Ariège-Pyrénées, LXV-LXVI, 2010-2011, Tarascon sur Ariège, France.

Yanicki, Gabriel, and John W. Ives

2017 Mobility, Exchange, and the Fluency of Games: Promontory in a Broader Sociodemographic Setting. In Prehistoric Games of North American Indians: Subarctic to Mesoamerica, edited by Barbara Voorhies, pp. 139-162. University of Utah Press, Salt Lake City.

Zedeño, Maria Nieves

2009 Animating by Association: Index Objects and Relational Taxonomies. Cambridge Archaeological Journal 19:411-421.

Zeanah, W. David, and Steven R. Simms

1999 Modeling the Gastric: Great Basin Subsistence Since 1982 and the Evolution of General Theory. In Models for the Millennium: Great Basin Anthropology Today, edited by Charlotte Beck, pp. 118-140. University of Utah Press, Salt Lake City.

Zilhão, João

2007 The Emergence of Ornaments and Art: An Archaeological Perspective on the Origins of "Behavioral Modernity." Journal of Archaeological Research 15:1-54.

Submitted June 20, 2018; Revised July 25, 2018; Accepted August 10, 2018 